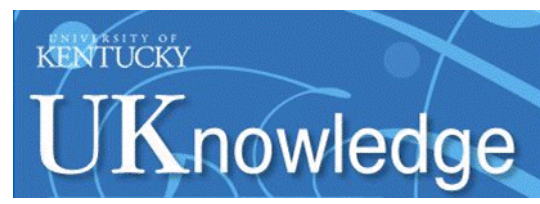

Kentucky Law Journal

1999

\title{
The Privatization of Business and Commercial Dispute Resolution: A Misguided Policy Decision
}

Chris A. Carr

California Polytechnic State University

Michael R. Jencks

Jencks Law Group

Follow this and additional works at: https://uknowledge.uky.edu/klj

Part of the Business Organizations Law Commons

Right click to open a feedback form in a new tab to let us know how this document benefits you.

\section{Recommended Citation}

Carr, Chris A. and Jencks, Michael R. (1999) "The Privatization of Business and Commercial Dispute Resolution: A Misguided Policy Decision," Kentucky Law Journal: Vol. 88: Iss. 2, Article 2.

Available at: https://uknowledge.uky.edu/klj/vol88/iss2/2

This Article is brought to you for free and open access by the Law Journals at UKnowledge. It has been accepted for inclusion in Kentucky Law Journal by an authorized editor of UKnowledge. For more information, please contact UKnowledge@lsv.uky.edu. 


\title{
KENTUCKY \\ LAW JOURNAL
}

NUMBER 2

\section{ARTICLES}

\section{The Privatization of Business and Commercial Dispute Resolution: A Misguided Policy Decision*}

\author{
BY CHRIS A. CARR"* \\ \& MICHAEL R. JENCKS ${ }^{* *}$
}

TABLE OF CONTENTS

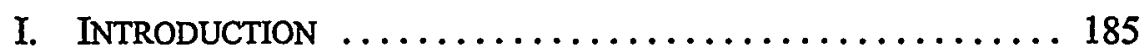

II. THE ROLE OF THE COMMON LAW AND SYSTEM OF PRECEDENT IN THE RESOLUTION OF BUSINESS DISPUTES . . . . . . . . . 189

A. Precedent Defined ........................ 190

- Copyright (C) 2000, Chris A. Carr and Michael R. Jencks.

* Assistant Professor of Business Law and Public Policy, California Polytechnic State University, San Luis Obispo, California. B.S. 1987, University of Nebraska, Lincoln; J.D. 1990, Santa Clara University School of Law; M.A. 1998, University of California, Los Angeles. Of Counsel, Jencks Law Group, Arroyo Grande, California.

*** Principal, Jencks Law Group, Arroyo Grande, California. B.A. 1969, Williams College; J.D. 1972, Boalt Hall School of Law, University of California, Berkeley; 1972-1974, Law Clerk to the Honorable William T. Sweigert, Senior U.S. District Judge for the Northern District of California. 
B. Why Courts Use Precedent ................... 191

C. How Courts Use Precedent in Business Cases ......... 192

III. The Changing NATURE OF BUSINESS TRANSACTIONS AND

DiSPUTES ..................................... 194

A. Increased Internationalization ................ 194

B. The Proliferation of Secondary Rights and Case Complexity 195

C. Increased Speed ......................... 197

D. Disaffection with the New Law Merchant . .......... 197

IV. BUSINESSES TURNING TO PRIVATE ALTERNATIVE DISPUTE

RESOLUTION ............................ 198

A. Perceived Court Congestion and Delay ............ 200

B. Expense ........................... 202

C. Perceived Juror Ignorance and Bias Against Business ... 204

D. Perceived Lack of Expertise in the Judges Presiding Over Business Disputes ....................... 205

E. Privacy and Confidentiality ................. 208

F. The Advertised Ability of ADR to Provide "Win-Win"

Business Solutions and Preserve Business Relationships .. 209

V. Changes IN How Courts SERVICE BUSINESS DisPuteS .... 211

A. Managerial Judging ..................... 212

B. The Bureaucratization of the Judiciary ............ 213

C. Courts Forcing Business Cases into ADR ........... 213

D. Vacatur, Selective Publication and No-Citation Rules, Depublication, and Filings Under Seal and Confidential

Settlements ............................ 215

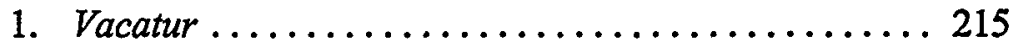

2. Selective Publication and the No-Citation Rule ..... 216

3. Depublication ......................... 219

4. Filings Under Seal and Confidential Settlements .... 220

VI. THE INSTITUTIONAL PRACTICE OF LAW FURTHERING THE PRIVATIZATION OF BUSINESS DISPUTE RESOLUTION ....... 221

VII. ADDITIONAL DANGERS POSED BY THE PRIVATIZATION Process .............................. 228

A. The Loss of Information and Reduction of the Public

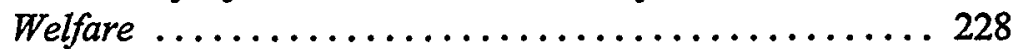

B. Widening the Gap Between the "Haves" and "HaveNots".............................. 230

C. A Reduction in the Power of the Courts ........... 231

VIII. PROPOSALS FOR REFORM $\ldots \ldots \ldots \ldots \ldots \ldots \ldots \ldots . \ldots . \ldots . \ldots . \ldots$

A. Course Corrections to Help Maintain a Sufficient Quantity and Variety of Business Cases at the Trial Court Level . . . . 233 
1. Recommendation One-Expand the Pool of Judicial Candidates ......................... 237

2. Recommendation Two-Improve Judicial Continuing Education in Business and Commercial Practices .... 237

3. Recommendation Three-Increase the Use of Law Clerks and Research Attorneys to Support Judges . . . 237

4. Recommendation Four-Increase Scrutiny of Fee Applications ....................... 238

5. Recommendation Five-Businesses Must Become Informed Consumers of Legal Services ........... 240

B. Course Corrections to Help Increase the Availlability and

Use of Decisions . ...................... 241

1. Recommendation Six-Provide More Appellate Judges 241

2. Recommendation Seven-Permit Citation of Any Decision by an Appellate Court of Record ........ 242

3. Recommendation Eight-Bar the Practice of Depublication ....................... 242

IX. ConCLUSION $\ldots \ldots \ldots \ldots \ldots \ldots \ldots \ldots \ldots \ldots \ldots \ldots \ldots \ldots$

\section{INTRODUCTION}

Come gather and sing to the Common Law whose leaf and seed we are, Whether we live by the waggling jaw or counsel, miles from the Bar. The wood is good and the sap is strong that gave us Coke and Hale, Right is a battle to win from Wrong, in spite of contempt and jail. It calls for brain and it calls for will, but an acorn knows his mission: Law is the Oak of Liberty still, in the Common Law Tradition. Rowdy dowdy doodle-ee-o In the Common Law Tradition. Rowdy dowdy doodle-ee-o In the Common Law Tradition. ${ }^{1}$

7 he common law, and how it develops rules for allocating risk and deciding business and commercial disputes through a body of reported public decisions, has provided a framework for governing commercial trade and commerce that many countries have

${ }^{1}$ MARY ANN GLENDON, A NATION UNDER LAWYERS: HOW THE CRISIS IN THE LEgAL PROFESSION IS TRANSFORMING AMERICAN SOCIETY 177-78 (1994). Professor Glendon writes that when she was a law student at the University of Chicago in 1959, Professor Karl Llewellyn entered the classroom on the last day of her Elements of the Law course and invited the students to join him in singing this ballad he composed. See id. 
adopted today. ${ }^{2}$ Relatedly, four scholars from Harvard University and the University of Chicago recently credited the common law as a reason why certain countries develop at a more advanced rate than others. ${ }^{3}$ The common law, with its tradition of stability and predictability, is also often cited as an important reason why companies are attracted to particular

2 See RAY AUgust, INTERNATIONAL Business LAW 42 (2d ed. 1997) (reproducing a map depicting the distribution of the world's legal systems).

${ }^{3}$ Rafael La Porta, Florencio Lopez-de-Silanes, and Andrei Shleifer of Harvard University, and Robert Vishny of the University of Chicago, divided the legal systems of the world into four categories based on histories:

- English common law relying on case precedents: Countries in this group include Britain and its former colonies ranging from the United States, Canada, Hong Kong, Singapore and Australia.

- Civil law relying on the classification of rules by legal scholars: This category is broken down into three subcategories:

- French civil law nations: Countries in this group include France, Indonesia, Spain and Mexico.

- German civil law nations: Countries in this group include Japan, South Korea and Taiwan.

- Scandinavian law nations: This group is limited to the Scandinavian nations.

These scholars reached a number of conclusions:

- Common law nations are the most:

1. Protective of shareholder rights.

2. Protective of creditor rights.

3. Enforcers of laws.

- French civil law nations are the least:

4. Protective of shareholder rights.

5. Protective of creditor rights.

6. Enforcers of laws.

- German civil law nations fall in between, but are very close to common law nations in protecting creditor rights.

The Law of the Market, ECONOMIST, Apr. 19, 1997, at 78. See also RAFAEL LA PORTA ET AL., LAW AND FINANCE (National Bureau of Econ. Research, Working Paper No. 5661, 1996); RAFAel LA PORTA ET AL., LEGAL DETERMINANTS OF EXTERNAL FINANCE (National Bureau of Econ. Research, Working Paper No. $5879,1997)$. These scholars also found that stock markets in these countries reflect these differences. Where protections are the greatest, markets are the strongest. In particular, they state: "In the typical common-law country, the value of the stockmarket is equal to around $60 \%$ of GNP. In civil-law countries, the authors find, markets tend to be far smaller. French-[civil] law countries, for example, have an average market capitalisation ratio of only $21 \%$ of GNP." The Law of the Market, supra. 
countries and states to conduct business. ${ }^{4}$ Further, with respect to the area of intellectual property:

[T] he common law has emerged as a source of protection for intellectual property rights throughout this century whenever statutory protection for new forms of media were still evolving. This phenomenon results from the relationship between communication technologies, which are dynamic and often difficult to anticipate, and statutes, which traditionally have been adopted only in reaction to such changes. ... [ [ ] $\mathrm{n}$ cases in which statutory protection may not readily apply to new technologies, intellectual property owners have repeatedly and successfully resorted to common law theories for legal solutions to new problems.

${ }^{4}$ See Robert SteWART, BERMUdA: AN ECONOMY Which WORKS (1997) (pointing out that one of the major reasons why international companies are attracted to Bermuda is its. English common law system and the objective, public decisions rendered by Judicial British Committee of the Privy Council-often described as the Commonwealth's Supreme Court). Donald Conlon and Daniel Sullivan note that a key reason why many companies incorporate in Delaware is because of its:

[Two hundred] plus years of case law. In its breadth and depth, this body of law goes further than similar bodies of law in other states toward meeting corporate needs for certainty and predictability.... Organization theorists have long recognized the importance of reducing uncertainty by controlling or managing elements of the external environment, such as the legal environment (citations omitted).

Donald E. Conlon \& Daniel P. Sullivan; Examining the Actions of Organizations in Conflict: Evidence from the Delaware Court of Chancery, ACAD. OF MGMT. J., June 1999, at 320.

${ }^{5}$ Bruce P. Keller, Condemned to Repeat the Past: The Reemergence of Misappropriation and Other Common Law Theories of Protection for Intellectual Property Rights, 11 HARV. J. L. \& TECH. 401, 403 (1998). Keller also notes: Litigants in the online world have [also] resorted to a variety of common law claims to address problems such as junk e-mail and hacking. Future advances, even in such commonplace technologies as television, are equally likely to result in the assertion of ... common law theories.

This pattern at first seems odd, particularly considering that the technological advancements that spawn new communicative endeavors also create a strong desire to organize such endeavors within a comprehensive legislative framework. On reflection, however, the immediate resort to common law theories is understandable. Although it is true that the myriad scenarios resulting from developing technologies spur proposed legislative solutions, that process, in itself, poses two problems. First, it takes time to 
In short, the common law's accomplishments with respect to trade and commerce are impressive. Today, however, our courts and system for developing commercial precedent are under attack, perhaps more than ever before. Private alternative dispute resolution ("ADR") as a method for resolving business disputes is "hot"-courts and traditional litigation are not. ${ }^{6}$ Yet, in light of the common law's track record, it is more than ironic that business and commercial dispute resolution is becoming more and more privatized, thereby stunting the growth and development of the very body of law that has traditionally served business so well. ${ }^{7}$

get legislation enacted. Second, even the most forward looking statute cannot anticipate all technological controversies. As a result, statues have way of lagging behind real life. This lag sometimes leaves litigants in a bind, particularly owners of intellectual property rights who may believe their rights have been violated in a manner not explicitly addressed by statutory schemes. Common law, on the other hand, is more adaptable. A court presented with a novel set of facts can review prior case law, analyze new factual situations, and, reasoning from past precedent, apply existing legal principles to fashion a new rule governing the heretofore unanticipated set of facts facing the court. This was demonstrated repeatedly throughout the twentieth century when new technologies, or new uses of existing technologies, generated novel intellectual property disputes. When entities that had invested heavily to create commercially valuable assets felt threatened by those who tried to piggyback on the public's fascination with a product or service not fully protected by intellectual property law, they relied on common law theories ... to protect their interests.

Id. at 403-05. See also M. Stuart Madden, The Vital Common Law: Its Role in a Statutory Age, 18 U.ARK.LITTLEROCKL.J. 555 (1996) (describing the vitality and adaptability of the common law).

${ }^{6}$ See, e.g., Derek Bok, A Flawed System, HARV. MAG., May-June, 1983, at 38 (cited in Owen M. Fiss, Against Settlement, 93 YALE L.J. 1073, 1073 n. 2 (1984)) (decrying "the familiar tilt in the law curriculum toward preparing students for legal combat," and exhorting law schools to train their students "for the gentler arts of reconciliation and accommodation"); Warren E. Burger, Isn't There a Better Way?, 68 A.B.A. J. 274 (1982); Warren E. Burger, Agenda for 2000 A.D.-A Need for Systematic Anticipation, 70 F.R.D. 83, 93-96 (1976); Carolyn Kleiner, The Action Out of Court, U.S. NEWS \& WORLD REP., Mar. 29, 1999, at 91 (noting the rise of law school $A D R$ programs).

${ }^{7}$ Professor John Fleming reminds us that the very nature of a vibrant and healthy common law legal system involves conflict. He writes: "A great deal of human activity ... involves conflict with opposing interests of others. ... [O]ur capitalist system, countenances if not actively encourages friction in which one enterpriser advances himself at the cost of another for the assumed good of society 
The primary purpose of this Article is to revisit the role and importance of the common law and our system of precedent, highlight how the development of the contemporary body of commercial law is being thwarted and distorted through various privatization processes, discuss why these privatization processes are shortsighted and erroneous, and most importantly, suggest proposals for reform. Part II revisits the important role that courts and the system of precedent play in the prevention and resolution of business disputes. Part III addresses ways in which business transactions and disputes have changed over the years and how courts have sometimes struggled to service them. Part IV discusses how those changes have resulted in businesses increasingly turning to private ADR - the first level of privatization-to resolve disputes. Part $V$ addresses a second form of privatization: (1) managerial judging; (2) the bureaucratization of the judiciary; (3) the attempt by courts to decrease their workload and conserve judicial resources by diverting business cases into ADR; and finally, (4) the increased use of vacatur, selective publication and the adoption of nocitation rules, depublication, filings under seal and confidential settlements. Part VI explores how these privatization processes have been (and continue to be) furthered and accelerated by changes in the institutional practice of law-namely, through the advent of the "discovery lawyer" at many corporate law firms.

Standing alone, none of these developments may be cause for concern. However, as pointed out in Part VII, the cumulative effects of these privatization processes pose significant dangers to the business community and society. Part VIII concludes the Article, pointing out that this privatization movement is shortsighted and erroneous. It also proposes that several course adjustments be made so that our courts and the common law can become more important and attractive instruments in regulating and evolving business and commerce.

\section{THE ROLE OF THE COMMON LAW AND SYSTEM OF PRECEDENT IN THE RESOLUTION OF BUSINESS DISPUTES}

A foundational principle of American society is to provide citizens-including businesses-with access to legal and political processes that are open to public scrutiny. ${ }^{8}$ Yet the widespread privatization of

generally." JOHN G. FLEMING, AN INTRODUCTION TO THE LAW OF TORTS 215 (1985) (emphasis added).

8 See, e.g., LAW AND PUBlic POLICY COMM. OF THE SOCIETY OF PRofessionals IN DisPUTE RESOLUTION, PUBLIC ENCOURAGEMENT OF PRIVATE 
business disputes limits the development of such a system. It also distorts the development of a contemporary body of commercial law. Before we allow or encourage our courts to become even more removed from this process, it is helpful to revisit the role of precedent in the development of commercial law.

\section{A. Precedent Defined}

Precedent is defined as "an adjudged case or decision of a court of justice, considered as furnishing a rule or authority for the determination of an identical or similar case afterwards arising, or a similar question of law." Stare decisis, the doctrine that courts should follow precedent in deciding cases, has been in place for centuries ${ }^{10}$ and remains "the everyday working rule of our law."11 In law school, through the use of the case method, students are taught how to identify and use precedent. More specifically, future attorneys and judges are taught to identify the holding of a case within the context of the particular dispute, and then analyze and evaluate its precedential effect. This process is more than merely academic and does not end upon graduation from law school. Young trial attorneys soon learn that judges-at least the good ones-do

DISPUTE RESOLUTION: IMPLICATIONS, ISSUES AND RECOMMENDATIONS (1993), reprinted in CENTER FOR PUBLICRESOURCES, JUDGE'SDESKBOOKONCOURT ADR 87 (Elizabeth Plapinger et al. eds., 1993) (noting that a "hallmark of our system of democratic government has been that private individuals, including the disadvantaged or less powerful segments of our society, have access to the political and legal processes, and that governmental decisionmaking is open to public scrutiny").

${ }^{9}$ BLACK'S LAW DICTIONARY 1195 (7th ed. 1999).

${ }^{10}$ See I SIR WILLIAM BLACKSTONE, COMMENTARIES 68-74 (1775):

For it is an established rule to abide by former precedents, where the same points come again in litigation: as well as to keep the scale of justice even and steady, and not liable to waiver with every new judge's opinion; and also because the law in that case being solemnly declared and determined, what before was uncertain, and perhaps indifferent, is now become a permanent rule which is not in the breast of any subsequent judge to alter or vary from according to his private sentiments: he being not delegated to Id. pronounce a new law, but to maintain and expound the old one.

11 BenJamin N. Cardozo, THe Nature of the Judicial Process (1921), reprinted in SELECTED WRITINGS OF BENJAMIN NATHAN CARDOZO, at 112 (Margaret E. Hall ed., 1947). 
in fact "examine and compare"12 precedent, and that the modification and development of precedent depends upon a change in the holdings of individual courts about specific disputes. ${ }^{13}$ When this process is properly implemented and followed, in the words of Judge Learned Hand, our body of commercial law grows like a "monument slowly raised, like a coral reef."14

\section{B. Why Courts Use Precedent}

Different theories exist as to why courts use precedent. One holds that prior judicial decisions serve as the "public record of the 'unwritten law,' customs and legal traditions, acquiring both their meaning and authority from recognition as part of the collective wisdom or reason." "15 Under this theory, "precedent helps establish a smooth transition between the accumulated experience of the past, evidenced by judicial decisions, and the present, to which the reasoning of the prior decision is applied, unless the present court determines that the prior court's reasoning was in error." ${ }^{.16}$

Another theory provides that precedent is powerful and used by courts not because it represents society's collective wisdom or reasoning, but because of the authority of the judiciary. ${ }^{17}$ Under this view, the judiciary, as the sovereign, has the authority and right to establish a legal framework by which rules can be known, legal consequences can be predicted, and public expectations can thereby be protected. ${ }^{18}$ Jeremy Bentham advocated

${ }^{12}$ Id.

${ }^{13}$ See id. at 114.

${ }^{14}$ Learned Hand, Judge Cardozo's The Nature of the Judicial Process, 35 HARV. L. REV. 479, 479 (1922) (book review). Judge Hand wrote: "[Common law] stands as a monument slowly raised, like a coral reef, from the minute accretions of past individuals, of whom each built upon the relics which his predecessors left, and in his turn left a foundation upon which his successors might work." Id.

${ }^{15}$ Mark D. Hinderks \& Steve A. Leben, Restoring the Common in the Law: A Proposal for the Elimination of Rules Prohibiting the Citation of Unpublished Decisions in Kansas and the Tenth Circuit, 31 WASHBURN L. J. 155, 170 (1992).

\footnotetext{
${ }^{16} I d$.

${ }^{17}$ See id.

${ }^{18}$ See id.
} 
this view centuries ago, ${ }^{19}$ and his concern with stability and predictability can also be found in the writings of contemporary jurists. ${ }^{20}$

\section{How Courts Use Precedent in Business Cases}

Courts use precedent in business cases in a variety of ways. First, they look to precedent to help resolve the dispute at hand. ${ }^{21}$ Professor Melvin Eisenberg notes the following with respect to how courts accomplish this task:

Complex societies characteristically need an institution that can conclusively resolve disputes deriving from a claim of right based on the application, meaning, and implications of the society's existing standards. In our society that institution is the courts, and the resolution of such disputes is accordingly a central function of our courts. This centrality is manifested in a variety of ways. To begin with, courts in our society are structured to be fundamentally passive. Unlike a legislature, a court may not properly initiate action on its own motion but may act only when set

\footnotetext{
${ }^{19}$ See Jeremy Bentham, $A$ Comment on the Commentaries, in A COMMENT ON THE COMMENTARIES AND A FRAGMENT ON GOVERNMENT 196-97, n.c (J.H. Burns \& H.L.A. Hart eds., 1977). Bentham wrote:

The deference that is due to the determination of former judgments is due not to their wisdom, but to their authority: not in compliment to dead men's vanity, but in concern for the welfare of the living. That men may be enabled to predict the legal consequences of an act before they do it: that public expectation may know what course it has to take: that he who has property may trust to have it still: that he who meditates guilt may look for punishment, and in the self-same guilt for the same punishment... Why should decisions be uniform? Why should succeeding ones be such as to appear the natural and expected consequences of those preceding them? Not because it ought to have been established, but because it is established.... The business of the Judge is to keep the distribution of valuables and of rewards and punishments in the course of expectation: conformable to what the expectation of men concerning them is, or if apprised of the circumstances of each case, as he is, he supposes would be.
}

Id.

${ }^{20}$ See, e.g., Hinderks \& Leben, supra note 15 , at $171 \mathrm{n} .96$. Hinderks and Leben note that Justice Cardozo believed in the general rule of following precedent in order to ensure the consistent protection of rights and litigants' belief that justice was evenhanded, consistent and fair.

${ }^{21}$ See MELVIN ARONEISENBERG, TheNATURE OF THE COMMONLAW 4 (1988). 
in motion by a party with a claim. Correspondingly, a court is limited to action that is responsive to the claim made. The kinds of claims the court may properly act upon are also limited. The claim normally must be contested-that is, the subject of a dispute. The claimant normally must assert that the respondent has either infringed (or threatens to infringe) upon his rights, or is otherwise at fault in a manner that sufficiently involves the claimant's interests to render it appropriate for him to make a claim whose disposition turns on that fault. The claim must be based on a standard that relates to [business norms] rather than, say, on an artistic standard. The standard on which the claim is based must rise to a certain level of significance, in terms of either the seriousness of the injury that typically results from its violation or the importance of the norm or policy that it reflects. ${ }^{22}$

Second, courts use precedent to further enrich the supply oflegal rules that govern business disputes. ${ }^{23}$ Eisenberg also writes:

Our society has an enormous demand for legal rules that actors can live, plan, and settle by. The legislature cannot adequately satisfy this demand. The capacity of a legislature to generate legal rules is limited, and much of that capacity must be allocated to the production of rules concerning governmental matters, such as spending, taxes, and administration; rules that are regarded as beyond the courts' competence, such as the definition of crimes; and rules that are best administered by a bureaucratic machinery, such as the principles for setting the rates charged by regulated industries. Furthermore, our legislatures are normally not staffed in a manner that would enable them to perform comprehensively the function of establishing law to govern action in the private sector. Finally, in many areas the flexible form of a judicial rule is preferable to the canonical form of a legislative rule. Accordingly, it is socially desirable that the courts should act to enrich that supply of legal rules that govern ... [business] conduct-not by taking on lawmaking as a free-standing function, but by attaching much greater emphasis to the establishment of legal rules than would be necessary if the courts' sole function was the resolution of disputes. ${ }^{24}$

${ }^{22} I d$. (footnotes omitted).

${ }^{23}$ See id.

${ }^{24}$ Id. at 4-5 (footnotes omitted). In her dissent in Neary v. Regents of the University of California, Justice Joyce Kennard of the California Supreme Court reminds us that not only do the courts resolve disputes and enrich the supply of 
In light of the above, the following question is presented: are today's courts beingutilized to their fullest potential in developing and refining our body of contemporary commercial law? Parts IV, V and VI point out that, for a variety of reasons, the answer is no. Part VII highlights the dangers of this development and why this policy is shortsighted and erroneous. Before this question can be addressed in detail, we must first consider how business cases have changed over the years and how those changes have challenged the courts' ability to efficiently resolve such disputes.

\section{The Changing Nature of Business TRANSACTIONS AND DISPUTES}

Our society has changed over the years, as have the nature of our business transactions and the resulting business disputes courts are being asked to resolve.

\section{A. Increased Internationalization}

In recent years we have witnessed the emergence and development of a global economy. ${ }^{25}$ We no longer live in a world in which local manufac

legal rules that govern those disputes, but their judgments also have "value for society at large." Neary v. Regents of Univ. of Cal., 834 P.2d 119, 130 (Cal. 1992). For example, Professor Marc Galanter points out that the court system and formal adjudication "project[s] the standards and threats that parties and lawyers use in "bargaining in the shadow of the law," "and it is because courts project such messages that "parties and lawyers are able to resolve the vast majority of disputes without burdening the courts"; in other words, the norms that courts broadcast to society "influence not only disputes that are brought to the courts, but also matters that never reach the courts." Marc Galanter, Real World Torts: An Antidote to Anecdote, 55 MD.L.REV. 1093, 1101-02 (1996). Similarly, Howard Slavitt writes:

The system of precedent also promotes the protection of private rights and the resolution of disputes. The system of precedent makes the law more certain and uniform because it allows courts separated geographically and temporally to exchange their decisions and reasoning. It creates guidelines within which individual judges must operate to avoid reversal. By making the law more certain, it also allows individuals to structure their affairs to avoid disputes and litigation.

Howard Slavitt, Selling the Integrity of the System of Precedent: Selective Publication, Depublication, and Vacatur, 30 HARV. C.R.-C.L. L. REV. 109, 140 (1995) (footnotes omitted) (emphasis added).

${ }^{25}$ See RICHARD SCHAFFER ET AL., INTERNATIONAL BUSINESS LAW AND ITS ENVIRONMENT 4-6 (4th ed. 1999) (noting the arrival of a global marketplace due 
turers use local materials and labor to create a product for sale only in a local market. Instead, many products are made for a national or international market. It is not uncommon for manufacturers to "obtain raw materials or parts in one country, perform subassembly in another country, [with] final assembly [occurring] in yet another, then deliver [the] products 'just in time' to customers in several countries."26 This phenomenon has presented difficult and complex choice of forum, choice of law, discovery, and judgment enforcement issues for courts, especially state courts unfamiliar with such issues. ${ }^{27}$

\section{B. The Proliferation of Secondary Rights and Case Complexity}

It is not only the increased internationalization of the marketplace that has presented courts with new and difficult business disputes to resolve; there has also been a proliferation of "secondary rights" in many types of business cases. This has in turn significantly increased the complexity of many business disputes. Some commentators label this development the "law of contorts." ${ }^{\text {"28 }}$ By way of example, twenty years ago a dispute

to recent political and economic events).

${ }^{26}$ Byron Acohido, Expansion Express-Airlines, Air-Freight Companies Enter High Stakes Arena of Global Delivery, SEATTLE TIMES, June 3, 1990, at E1. See also, SCHAFFER ET AL., supra note 25, at 484 (discussing how a Japanese automaker can produce cars in a Mexican assembly plant using parts sourced from countries around the world, and then export those Mexican-made cars to the United States).

27 See SCHAFFer ET AL., supra note 25, at 105-30; CHARLES PlatTo \& MICHAEL LEE, OBTAINING EVIDENCE IN ANOTHER JURISDICTION IN BUSINESS DISPUTES 181-90 (2d ed. 1993) (discussing the difficulty of conducting discovery and taking evidence abroad in England and the former West Germany). One of the authors recently represented several California companies who became entangled in litigation involving complex issues of international law due to their business activities. Several years ago, these companies were not even selling their products outside of the West Coast, let alone the United States, and they never would have been involved in such complex litigation.

${ }^{28}$ Elia Weinbach \& Sydelle Pittas, Contorts, in BUSINESS TORTs LITIGATION 108 (Litigation Section of the A.B.A., 1992) (footnote omitted). Weinbach and Pittas write:

The pun inherent in this chapter title is apt. As current concepts of justice and fair play dictate that the law be molded (some might say, contorted) to fit litigation arising from new and more complex business situations, the bright line between injuries that 'sound in contract' and in tort, and their consequent remedies, fades. Thus we come to the law of contorts. Id. 
between a law firm and its client over fees, to the extent that unpaid fees were even pursued, normally consisted of the law firm filing a complaint for breach of contract, with the client in turn filing an answer that alleged a few straightforward affirmative defenses. Discovery in the case was clean and simple, as were the legal issues. Today, that same dispute results in the client not only filing an answer, but a counterclaim for professional negligence (usually for leverage purposes), and the cost and complexity of the case is thereby significantly increased. Similarly, in the past a licensor who licensed a patent to a licensee and then discovered that the licensee was misusing the patent was likely to allege that the right that had been violated was the licensing agreement (i.e., it was breached). Today, that same case will see a plethora of secondary rights-"contorts"-come into play based on contract law, federal patent law, and unfair competition law:Specifically, as in the past, the licensor's complaint will allege a cause of action for breach of the licensing agreement. But it will also allege a cause of action for patent infringement-in part to attempt to obtain the benefit of treble damages ${ }^{29}$ versus typical breach of contract damages. Also, the licensee will bring its own counterclaim for unfair competition and antitrust violations. In a nutshell, these secondary rights often transform what used to be a relatively straightforward business case into the exact opposite..$^{30}$

${ }^{29}$ See 35 U.S.C. $\$ 284$ (1994).

${ }^{30}$ See generally Jeffrey W. Stempel, A More Complete Look at Complexity, 40 ARIZ. L. REV. 781, 819 (1998) ("[I]t seems fair to conclude that there has been major growth ... of complex cases."). Stempel's article provides a good discussion (but from a different angle) on the growth of complexity in commercial cases. See also Christine Gail Clark, Comment, The Sky is Falling-The ALI's Efficient Response to Courts in Crisis?, 1995 BYU L. REV. 997, 1003-16 (discussing the increased complexity in cases due to the multiple parties now involved, the complexity in pretrial proceedings, the complexity during trial, and the complexity in choosing and administering remedies); Alvin $\mathrm{B}$. Rubin, Bureaucratization of the Federal Courts: The Tension Between Justice and Efficiency, 55 NOTRE DAME L. REV. 648, 649 (1980) ("Our 1940 cases were largely one or two issue matters. Today appeals involve records of thousands of pages and briefs arguing dozens of issues.").

Relatedly, the arrival and availability of class and derivative actions has also challenged the ability of the courts to resolve disputes. For example, class actions involving asbestos exposure have posed complex choice of law problems for the courts. See In re Joint E. \& S. Dist. Asbestos Litig., 878 F. Supp. 473 (E.D.N.Y. 1995). The Agent Orange cases have also pushed courts to their limits. See generally Peter H. Schuck, The Role of Judges in Settling Complex Cases: The Agent Orange Example, 53 U. CHI. L. REV. 337 (1986). 


\section{Increased Speed}

Many of today's business transactions and markets, especially in an era of electronic commerce, move faster than ever before. Take Internet entrepreneurs as an example. In the past such entrepreneurs did not think in terms of the patentability of their business ideas and inventions. ${ }^{31}$ Yet the market is now forcing them to do so, and they are discovering that it can take eighteen months just for a patent to be issued, ${ }^{32}$ let alone litigate any related ownership dispute in the courts. By the time such litigation is resolved, "the cyber-marketplace will have changed several times over,"33 thereby often making the end-result of the litigation irrelevant. In short, courts sometimes find it difficult to keep pace with a marketplace that demands such quick resolutions. ${ }^{34}$ Another example is the venture capital arena. Today, "most venture capitalists look for companies that can provide liquidity in three to five years. ${ }^{935}$ The venture capital process now moves so quickly that it can be fatal for a start-up company to be tied up in litigation to sort out its "legal messes," even for a short period of time.

\section{Disaffection with the New Law Merchant}

Marc Galanter points out that in our society certain "indigenous forums" exist that operate by "codes of conduct" independent of the law. ${ }^{36}$ Professor Robert Cooter adds that with respect to trade and commerce, many business communities are self-regulating and promulgate their own

${ }^{31}$ See Wendy R. Leibowitz, Lawyers and Technology: Patents and E-Business, NAT'L L.J., June 14, 1999, at A19.

${ }^{32}$ See id.

${ }^{33}$ Id. See generally Wendy R. Leibowitz, Lawyers and Technology: Let's Settle This, Online, NAT'LL.J., July 5, 1999, at A20 (noting the proliferation of web sites devoted to online ADR to help businesses resolve disputes more quickly).

${ }^{34}$ To speed up business dispute resolution, many courts have implemented "rocket dockets" or "fast-track" systems. See Carrie E. Johnson, Comment, Rocket Dockets: Reducing Delay in Federal Civil Litigation, 85 CAL. L. REV. 225 (1997); Michael A. Friedrichs, Note, Fast Track: A Panacea for a Delayed and Cluttered Court System?, 1 SAN DIEGO JUST. J. 443 (1993). But the efficacy and quality of these systems is unclear. See Johnson, supra, at 238-54; Friedrichs, supra, at 44956.

${ }^{35}$ CONSTANCE E. BAgley \& CRAig E. DAUCHY, THE ENTREPRENEUR'S GUIDE TO BUSINESS LAW 191 (1998).

${ }^{36}$ See Marc Galanter, Compared to What? Assessing the Quality of Dispute Processing, 66 DENV. U. L. REV. xi, xiii (1989). 
norms, rules, and enforcement mechanisms. ${ }^{37}$ As examples, he cites such professions as accounting and law, and "formal networks like Visa [that] promulgate their own rules." ${ }^{38}$ Cooter creatively labels such norms and rules the "new law merchant."39 Yet when businesspersons become disaffected with the "new law merchant" that governs their particular industry, they often turn to the courts as a last resort for help. ${ }^{40}$ As an example, consider the entrepreneurs who become entangled in domain name disputes and subscriber problems with Internet service providers. One would think that the norms (or "new law merchant") of that industry would make it ideal for the disputing parties to sit down and resolve the matter short of a lawsuit. ${ }^{41}$ Yet the opposite is occurring. Many of these parties instead want their day in court-yet again requiring the courts to address a new, different, and complex type of business dispute. ${ }^{42}$

\section{T. BUSINESSES TURNING TO PRIVATE ALTERNATIVE DISPUTE RESOLUTION}

We now return to the question earlier posed: are today's courts being utilized to their fullest potential in developing and refining our body of

${ }^{37}$ See Robert D. Cooter, Decentralized Law for a Complex Economy, 23 SW. U. L. REV. 443, 443-46 (1994).

${ }^{38} \mathrm{Id}$. at 445 (footnote omitted).

${ }^{39} \mathrm{Id}$.

${ }^{40}$ See Timothy P. Terrell \& James H. Wildman, Rethinking "Professionalism," 41 EMORY L.J. 403 (1992). Terrell and Wildman note:

[T]he legal system embodies our last remaining vestige of a sense of "community" - of shared values and expectations. All the other dimensions of our lives-race, religion, education, the arts, regional loyalty, and so on-divide us as much as they join us together because they are based on matters of "substance" on which we so often disagree.

Id. at 422. They further argue:

[W]e are connected to each other in the nature of the claims we make against each other: we do not ordinarily result to self-help or depend upon various informal social groups like churches, families, or friends to take up our cause. Instead, we invoke our system of law, both because we have come to have faith in it and because we have largely abandoned other alternatives.

Id. at 423.

${ }^{41}$ See Leibowitz, supra note 31, at A20 (describing recent cyber efforts aimed at mediating domain name disputes and subscriber problems with Internet service providers).

${ }^{42}$ See id. (noting that this cybermediation effort was unsuccessful because the "parties wanted their day in a real-world court"). 
contemporary commercial law? Similarly, have courts done a good job of adapting to the changes in the nature of business transactions and disputes earlier discussed? If business behavior is used as the primary indicator in answering this question, many would say that the answer is no, as over the past several decades businesses have been increasingly turning to private ADR to resolve their disputes. ${ }^{43}$ In this section, we discuss some of the

${ }^{43}$ In the early 1980 s several Fortune 500 companies founded the Center for Public Resources ("CPR") Institute for Dispute Resolution to explore private dispute resolution as an alternative to litigation when involved in a dispute with one another. A "CPR Pledge" was created in which member companies promised to explore ADR before litigating with each other. CPR obtained 50 signatories to that Pledge in 1983. By mid-1999, that number had grown to 4000 . CPR Corporate Policy Statement or Alternatives to Litigation (visited Nov. 4, 1999) $<$ http://www.cpradr.org/corppldg.htm>. In the early 1990s, a similar CPR Pledge was developed for law firms, which now has more than 1500 law firm signatories, including 400 of the nation's largest 500 law firms. See Law Firm Pledge (visited Nov. 4, 1999) <http://www.cpradr.org/lf_pol.htm>.

Recent surveys also confirm an increase in the use of private $A D R$ by American business. A 1994 survey conducted by Arthur Anderson LIP General Counsel and Corporate Legal Times found that almost $50 \%$ of those surveyed had used ADR within the last year-with $7.5 \%$ of these companies reporting an increase in use from the previous year. The Survey also found that large companies use ADR more than smaller companies. See Legal Costs and ADR Use, 13 ALTERNATIVES TOHIGH CosTLITIG. 141, 141 (1995); see also News From Around the States: Survey Shows Increase in Corporate ADR Use, 6 WORLD ARB. \& MEDIATION REP. 145, 145 (1995). In response to a 1994 CPR survey of corporate law firms, more than $80 \%$ indicated that client interest in ADR had increased over the previous three years. See SUSAN SCOTT, LAW FIRM PRACTICES IN ADR: 1994 SURVEY FINDINGS 10 (1995). A 1992 Business Week/Harris Executive poll found that $97 \%$ of the business executives surveyed stated that their companies favor making greater use of ADR. See Michele Galen, Guilty, Bus. WK., Apr. 13, 1992, at 66.

Private ADR providers also report a significant increase in business. The total number of private arbitrations and mediations handled through the American Arbitration Association ("AAA") alone has nearly doubled in the past decade, to a projected 90,000 in 1998. See Kleiner, supra note 6, at 90. AAA reports a significant increase in recent years in its real estate cases, computer cases, employment cases, franchise cases, and patent, trademark, and copyright disputes. See AAA DISP. RESOL. TTMES, Spring 1994, at 1. Judicial Arbitration and Mediation Services ("JAMS") saw its caseload increase from 8249 in 1990 to 18,049 in 1996. See John Gibeaut, At the Crossroads, A.B.A. J., Mar. 1998, at 61.

See also Mike France, More Big Businesses Ask: Can We Talk, Not Sue?, NAT'L L.J., Mar. 13, 1995, at B1 (reporting how the nation's biggest banks are considering signing an intra-industry treaty to turn to ADR before resorting to 
primary reasons for this development, but even more importantly, why many of these reasons may be grounded more on misconception than fact.

\section{A. Perceived Court Congestion and Delay}

For those who advocate an increased role for ADR in resolving business disputes, the point is often made that the courts are congested, rife with delay, and inaccessible due to a "litigation explosion."44 One commentator has noted that with the "excessive delays and exploding caseloads of the civil courts, many disputants view traditional litigation as unable to meet their conflict resolution needs. More and more parties are turning away from the judicial system and are resorting to private dispute resolution firms. ${ }^{\text {"45 }}$ Certainly, many business executives and their in-house counsel perceive that a litigation explosion has occurred. ${ }^{46}$

litigation, and that such intra-industry agreements have already been signed by top corporations in the food, commercial insurance, franchise and commercial inventory finance business); Jaret Seiberg, Capital Briefs: Justices Approve Mandatory Arbitration Clauses, AM. BANKER, May 22, 1996, at 2 (reporting a banking association lawyer's comment that the banking industry is making greater use of arbitration agreements); Bonnie Hayes, Lawsuit Boom? Here's Evidence to the Contrary, L.A. TIMES, Mar. 10, 1997, (Orange County Edition) at B3 ("[O]thers also credit an increase in arbitration for the decline in civil court cases. An increasing number of businesses, they say, are adding mandatory arbitration clauses to contracts."); Tom Arnold, A Better Mousetrap: ADR, Vol. XXX No. 1, LES NOUVELLES, at 31 (Mar. 1995) ("Beginning perhaps about 1987-1988 a number of major companies started making major shifts from Rambo or other strong litigation practice to ADR. Some of them were companies with 100 lawyers or so on staff-companies like Bank of America, Motorola, and major insurance companies."); Faye Riva Cohen, Advantages of Alternative Dispute Resolution (pt. 2), LEGAL INTELLIGENCER, Feb. 3, 1993, at 4, 21 (stating that "Business and insurance carriers are increasingly seeking to reduce the costs of civil litigation" and pointing out that to deal with the perceived problems in the legal system and to enhance their ability to compete, many companies are turning to ADR).

${ }^{44}$ See, e.g., Harry N. Scheiber, Innovation, Resistance, and Change: A History of Judicial Reform and the California Courts, 1960-1990,66 S.CAL.L.REV.2049, 2052 (1993) ("Complaints of a crisis in the courts, involving intolerable delays and congestion, in fact, have been heard regularly throughout the twentieth century-not only in California, but in many other states and in the federal courts.").

${ }_{45}^{45}$ Lucille M. Ponte, Putting Mandatory Summary Jury Trial Back On the Docket: Recommendations on the Exercise of Judicial Authority, 63 FORDHAML. REV. 1069, 1069 (1995) (footnote omitted).

${ }^{46}$ See John Lande, Failing Faith in Litigation? A Survey of Business Lawyers' and Executives' Opinions, 3 HARV. NEG. L. REV. 1, 26, 36 (1998) (indicating that 
The cause of this so-called litigation explosion has been the subject of intense debate. The list of proffered reasons includes the growing diversity and size of the American population, a heightened level of litigiousness among Americans, an increase in the number of judicially and statutorily created rights and a broadening of the definition of the class of people entitled to enforce those rights, expanded discovery, excessive lawmaking, and an increase in crime and criminal prosecutions (especially drug-related offenses) ${ }^{47}$ But what is interesting to note is that to the extent such an explosion has occurred, no study exists which suggests it has been disproportionately fueled by business cases. Further, Marc Galanter, other scholars, and even some judges point out that the claim of a "litigation explosion" is vastly exaggerated, if not outright false. ${ }^{48}$ Finally, many

$94 \%$ of the business executives and $82 \%$ of the in-house counsel surveyed believe that there has been a litigation explosion in the past ten years. In addition, $86 \%$ of the business executives and $79 \%$ of the in-house counsel surveyed believe that less than half of lawsuits involving business are resolved within an appropriate amount of time).

47 See Lawrence M. Friedman, Total Justice (1985); Donald L. HoROWITZ, THE COURTS AND SOCIAL POLICY (1977); BRUCE H. MANN, NEIGHBORS ANDSTRANGERS: LAW ANDCOMMUNITY INEARLY CONNECTICUT 10136(1987); Bayless Manning, Hyperlexis: OurNational Disease, 71 Nw.U.L.REV. 767 (1977); Wade H. McCree, Jr., Bureaucratic Justice: An Early Warning, $129 \mathrm{U}$. PA. L. REV. 777, 794-96 (1981); Judith Resnik, Managerial Judges, 96 HARV. L. REV. 376 (1982) [hereinafter Resnik, Managerial Judges]; Judith Resnik, Failing Faith: Adjudicatory Procedure in Decline, 53 U. CHI. L. REV. 494 (1986) [hereinafter Resnik, Failing Faith].

${ }^{48}$ See Galanter, supra note 24, at 1102-09 (noting that litigation rates have been relatively stable, and to the extent they have increased, these increases have only occurred in limited types of cases such as criminal law, family law, and certain types of product liability cases); Marc Galanter, Reading the Landscape of Disputes: What We Know and Don't Know (and Think We Know) About Our Allegedly Contentious and Litigious Society, 31 UCLA L. REV.4 (1983) (assessing the inaccuracy of the litigation explosion claim). See also DONNA STIENSTRA \& THOMASE. WILLGING, ALTERNATIVES TO LITIGATION: DO THEY HAVEA PLACE IN FEDERAL District CoURTs? 33 (Federal Judicial Center 1995) ("[T]n the aggregate, federal civil caseloads have been decreasing in recent years" and "the civil trial rate ... is already very low and has been steadily declining for the past decade in nearly all federal courts, those with ADR and those without ADR alike."); THOMAS E. BAKER, RATIONING JUSTICE ON APPEAL: THE PROBLEMS OF THE U.S. COURTS OF APPEALS 32 (1994) (noting the "hyperbole and metaphor" among those advocating court reform due to the increased number of cases); Jack B. Weinstein, After Fifty Years of the Federal Rules of Civil Procedure: Are the 
business executives and their corporate counsel are finding that private $A D R$ does not always live up to its billing in this regard, and if anything, often results in excessive delay. ${ }^{49}$

\section{B. Expense}

Private ADR is often touted as being cheaper than traditional litigation. ${ }^{50}$ Again, there is evidence that suggests that business executives

Barriers to Justice Being Raised?, 137 U.PA. L. REV. 1901, 1909 (1989) (asserting that the litigation explosion idea "is wrong as a matter of fact").

${ }^{49}$ See Harold Brown, Alternative Dispute Resolution Realities and Remedies, 30 SUFFOLK U. L. REv. 743 (1997). Professor Brown notes:

Timing factors can also be challenging. A fundamental attraction of ADR is its inherent promise of speedy and inexpensive process. [But] [w]ithout rules and a governing court, there is no limit to such crucial matters as the timing for pretrial logistics, the pace of the conduct of the proceedings, and the rendering of a speedy decision. While these matters might appear to be marginal, the fact is that arbiters are often ... pressed for time. They may have to extend the time limits to an extraordinary extent. For example, without explicit time regulations, there would be no way to compel the making of a final determination no matter how long the delay.

Id. at 767-68. See also Jeffrey G. Kichaven, ADR Does Not Save Time or Money? Great News!, DISP. RESOL. MAG., Summer 1997, at 15 ("[R]esearch by the RAND Institute for Civil Justice concludes mediation did not significantly affect the number of lawyer work hours or the time to disposition in the federal civil court programs it studied. In other words, ADR does not save time or money."); Arthur S. Hayes \& Ann Hagedorn, Arbitration in Commercial Cases Found to Save Money, Not Time, WALL ST. J., Sept. 5, 1990, at B10 (discussing another RAND study which found that arbitration in high-stakes commercial cases does not speed the process of resolving disputes).

${ }^{50}$ The CPR Institute for Dispute Resolution claims that for a five-year period ending in 1995, 652 companies using CPR panelists reported a total cost savings of over $\$ 200$ million, with an average cost savings of more than $\$ 300,000$ per company. See Fortune 500 Companies Find Benefits in Adopting ADR Policy (visitedDec. 30, 1999) <http://www.cpradr.org/poll_597.htm>.See also Ellen Joan Pollock, Mediation Firms Alter the Landscape, WALL. ST. J., Mar. 22, 1993, at B1 ("Since 1990, 406 companies ... saved more than $\$ 150$ million in legal fees and expert-witness costs by using litigation alternatives" in cases with an aggregate of over $\$ 5$ billion in dispute.); Arnold, supra note 43, at 33 ("[W]ith sophisticated use of ADR you can save millions of dollars. We have done patent infringement suits via $A D R$, as counsel, for $\$ 60,000$. In the courthouse it is hard to find the patent case where you can assure the client of a budget under a million."). 
and their in-house counsel at least perceive that the traditional court system is too expensive. ${ }^{51}$ However, due to a lack of empirical data, it is unclear whether ADR is, in fact, cheaper than traditional litigation. ${ }^{52}$ Some commentators contend that it is not, ${ }^{53}$ and as Marc Galanter notes, critics of the cost aspect of litigation often ignore the benefits:

51 See Lande, supra note 46 , at $35-36$ (stating that $96 \%$ of the business executives and $91 \%$ of the in-house counsel surveyed believe that less than half of the lawsuits involving a business are resolved at an appropriate cost).

${ }^{52}$ See Richard C. Reuben, The Dark Side of ADR, CAL. LAW., Feb. 1994, at 54 ("For all the promised benefits of $A D R$, independent statistics documenting them are almost nonexistent. One reason is the secrecy of the proceedings; few records exist for researchers to examine."); Editorial, Mandatory ADR: Can We Talk?, 78 JUDICATURE 272, 272 (May-June 1995) (noting the lack of empirical support for many ADR claims); Kim Dayton, The Myth of Alternative Dispute Resolution in the Federal Courts, 76 IOWA L. REV. 889, $906 \mathrm{n} .81$ (1991) ("One of the principal obstacles to conducting legitimate empirical research on the effect of ADR ... is the failure ... adequately to document the use and consequences of ADR.").

53 See Reuben, supra note 52, at 54 (citing an arbitration that produced a $\$ 15,000$ award and $\$ 6000$ in attorneys' fees but was more than offset by a $\$ 30,000$ legal bill and $\$ 9000$ for the arbitrator's services, and how, had the case stayed in the public system and gone to trial, the parties would not have had to even pay for the judge); id. at 57 (citing another example where an arbitrator submitted an unitemized discovery bill for $\$ 28,000$, and had the case stayed in the public court system, the discovery costs would have been the $\$ 14$ filing fee per motion, plus court reporters' fees); James J. Alfini, Summary Jury Trials in State and Federal Courts: A Comparative Analysis of the Perceptions of Participating Lawyers, 4 OHIO ST. J. ONDISP. RESOL. 213, 229-31 (1989) (citing a study in which a majority of the federal lawyers asserted that their billable hours increased when the ADR mechanism of a summary jury trial was used, and that few summary jury trial cases were actually completed within the half-day goal that was established); Robert J. Lewton, Comment, Are Mandatory, Binding Arbitration Requirements a Viable Solution for Employers Seeking to Avoid Litigating Statutory Employment Discrimination Claims?, 59 ALB. L. REV. 991, 1032 (1996) (noting that binding arbitration in employer-employee disputes may prove to be "just as expensive, time-consuming, and disruptive to litigate challenges brought against a mandatory, binding arbitration requirement as it is to litigate"); Kleiner, supra note 6 , at 91 (discussing a classroom exercise in which a school insurance company settled for an excessive sum because the other side misrepresented certain facts during the $A D R$ process, and that given the nature of the ADR process those misrepresentations went unchecked).

Further, Professor Brown writes:

The dollar cost of ... [ADR] may be substantial, particularly because it is totally supported by user fees. Some discovery may be avoided, but the 
[S]ociety's accounts should reflect not only the costs but the benefits of enforcing such transfers, which afford vindication, induce investments in safety, and deter undesirable behavior. For instance, the sums transferred by successful patent infringement litigation not only are not lost, but maintain the credibility of the patent system that in turn has powerful incentive effects. To put forward estimates of gross costs-even ones that are notmake-believe-as a sufficient guide to policy displays indifference to the vital functions that the law performs. ${ }^{54}$

\section{Perceived Juror Ignorance and Bias Against Business}

Another reason why businesses may be increasingly turning to private ADR is because they perceive that juries do a poor job determining liability and assessing damages in lawsuits against businesses and judge businesses more harshly than individuals. ${ }^{55}$ The following statement from a business executive is typical:

Is it any surprise that many commercial contracts these days have a clause where each party waives its right to a trial by jury? Doesn't that tell you something? That they are not willing to trust twelve peers off the street with the complexity of their business transaction . . . And that doesn't

daily charges of the impartial arbiters may substantially exceed such savings ... The arbitrator has exclusive power to order extensive and expensive discovery, thus wiping out much of the supposed economies. The hearing dates may greatly increase costs where the ever-busy arbitrator has other commitments that cause repeated postponements and delay, or interruptions to accommodate unrelated court assignments of counsel because courts seldom recognize any priority for conflicts with ADR.

Brown, supra note 49, at 760-61. He also points out that contrary to the ofttrumpeted claim of ADR being "less expensive," the dependence on user fees by such organizations as AAA often make ADR the exact opposite. See id. at 764-66.

${ }^{54}$ Galanter, supra note 24 , at 1142.

${ }^{55}$ See Lande, supra note 46 , at $33-34$ (indicating that $58 \%$ of the business executives and $46 \%$ of the in-house counsel surveyed believe that in less than half of cases do juries do a good job in determining liability in lawsuits by individuals against businesses; $82 \%$ of the business executives and $74 \%$ of the in-house counsel surveyed thought that in less than half of cases do juries do a good job of assessing damages. Further, $75 \%$ of the business executives and $73 \%$ of the inhouse counsel surveyed believe that juries judge businesses more harshly than individuals). 
mean that people are stupid. It means that businesses have become very complex in many respects. The nature of their product offerings, not necessarily how the business is run, but the nature of the products. Open up the insides of a laptop computer and try to have some jury decide whether or not there has been a patent infringement on the design of a microchip. I certainly wouldn't be capable of doing that. ${ }^{56}$

Yet, the research of Valerie Hans, William Lofquist and others strongly suggests that if anything, the contrary is true and that juries do know what they are doing and do give businesses the benefit of the doubt. ${ }^{57}$

\section{Perceived Lack of Expertise in the Judges Presiding Over Business Disputes}

In theory, another touted benefit of many forms of private ADR is the ability to select a "dispute resolver" with "expertise" in the business issue

${ }^{56}$ Id. at 34 (Apr. 15, 1994 interview quote from a business executive). See also Arnold, supra note 43, at 33 (making essentially the same point); Pollock, supra note 50 , at B1 ("Imagine a legal system in which companies could put their disputes before judges of their choice... [and] avoid the uncertainty of jury verdicts.").

${ }^{57}$ See Valerie P. Hans \& William S. Lofquist, Jurors' Judgments of Business Liability in Tort Cases: Implications for the Litigation Explosion Debate, 26 L. \& SOC'YREV. 85 (1992) (a study of jurors in cases involving businesses which found that most jurors were skeptical of plaintiffs' claims against businesses and did not generally believe that businesses should be held to a higher standard than individuals); Valerie P. Hans, The Contested Role of the Civil Jury in Business Litigation, 79 JUDICATURE 242 (1996) (pointing out that the criticisms that juries in business cases are pro-plaintiff, that their decisions are based more on sympathy and prejudice than facts, and that they focus on the business defendant's deep pockets appear unfounded). See also RALPH NADER \& WESLEY J. SMITH, No CONTEST: CORPORATE LAWYERS AND THE PERVERSION OF JUSTICE IN AMERICA 266-76 (1996) (noting that contrary to popular perception, juries are actually inclined to rule in favor of business). In support of their position, Nader and Wesley cite, among other things, the research of Jury Verdict Research, a Pennsylvania legal publishing company that compiles court statistics. See id. at 276. Marc Galanter adds that while our "courts could improve juror performance in many ways," "serious students of the jury are virtually unanimous in their high regard for the jury as a decision-maker" and "researchers concur that jurors on the whole are conscientious, that they collectively understand and recall the evidence as well as judges, and that they decide factual issues on the basis of the evidence presented." Galanter, supra note 24, at 1109. See also Edward Bodaken \& William Slusser, Want to Win Complex IP Trials? Simplify, Simplify, NAT'L L. J., July 26, 1999, at C11 (noting the simple, common-sense steps that a good trial lawyer can take to make a complex intellectual property case understandable to a jury). 
at hand. ${ }^{58}$ Judges in the traditional court system, on the other hand, are sometimes perceived to lack such expertise, ${ }^{59}$ especially by business executives. ${ }^{60}$ To the extent that a lack of such expertise exists, the

${ }^{58}$ See Mladen Singer, New Boundary: Arbitration in Various Discipline[s]: Commercial Arbitration as a Means for Resolving Industrial Property and Transfer of Technology Disputes, 3 CROAT. ARB. Y.B. 107 (1996):

A further advantage ... [of ADR] over litigation is the possible expertise of the arbitrators. It is particularly important in industrial property disputes that often involve complicated technical issues. Judges are usually not trained in technology, a problem in common law countries where factual determinations are made by juries. It requires extensive use of experts and/or expert witnesses, which is one of the things that makes industrial property litigation very expensive. However, even when experts or experts witnesses are used, the final decisions are brought by judges or juries, not by persons knowledgeable about the technology at stake. By using commercial arbitration, parties can have an adjudicator who is knowledgeable about both: respective industrial property laws, and a[bout] technology. Moreover ... arbitration panels can provide parties with extreme diversity of knowledge....

When making a list of arbitrators for patent disputes, American Arbitration Association (AAA) included people having expertise in all fields of technology and who also had a legal education.

Id. at 111-12.

${ }^{59}$ See Peter D. Zeughauser, What's in a Name? Plenty, AM. LAW., Apr. 1996, at 44. Zeughauser notes:

I had two maxims about litigation that served as the sobering cold water necessary to avoid costly litigation and instead engage in ADR: The first was that litigation is the sport of kings; the second was that the courtroom is a dangerous place. After all, what sober-minded business person wants an important dispute decided ... by a former D.A. who was appointed to the bench because of his or her skill in locking people away for crimes that were more often than not self-evident?

Id. Judge Jack Weinstein also makes the point that many judges come to the bench as generalists. See Jack B. Weinstein, Limits on Judges Learning, Speaking and Acting - Part I -Tentative First Thoughts: How May Judges Learn?, 36 ARIZ. L. REV. 539, 540-41 (1994).

${ }^{60}$ See Lande, supra note 46 , at 32 . Lande comments:

Yet another reason why ... executives reacted negatively to litigation is that they believed that it is not framed in terms of their substantive concerns, which they think are often too complex for the courts. This view was expressed by a utility company executive: "Judges are trained in the law, not necessarily in the fundamentals of a particular industry or avenue of commerce. They're coached on fairness and precedent and things like that. 
politicization of judicial selections ${ }^{61}$ and even their salaries ${ }^{62}$ may contribute to the problem. Yet the lack of expertise is by no means unique to judges in the traditional court system. If anything, businesses are finding that it may be even more acute with respect to many purported "ADR specialists. ${ }^{\circ 63}$

... For example, we have a number of disputes with people who we transact with in a transmission grid. Well, that's a very complex engineering-econometric type of consideration where we use those mechanisms. It's just not the type of thing you want to bring to the courts."

Id. Relatedly, Lande found that $67 \%$ of business executive respondents and $68 \%$ of in-house counsel respondents disagreed with the statement that "the legal system generally considers the needs and practices of particular business communities." Id. at 34-35.

${ }^{61}$ For an interesting historical discussion on the selection of federal judges and the politicization of the process, see SHELDON GOLDMAN, PICKING FEDERAL JUDGES: LOWER COURT SELECTIONFROM ROOSEVELT THROUGH REAGAN (1997). For the same regarding President Bush's appointees, see Sheldon Goldman, Bush's Judicial Legacy: The Final Imprint, 76 JUDICATURE 282 (Apr.-May 1993). For the same regarding President Clinton's appointees, see Sheldon Goldman \& Elliot Slotnick, Clinton's Second Term Judiciary: Picking Judges Under Fire, 82 JUDICATURE 264 (May-June 1999).

${ }^{62}$ See William C. Smith, Bailing From the Bench, A.B.A. J., May, 1999, at 22 (discussing how the disparity between law firm salaries and judicial salaries is driving experienced judges from the bench).

${ }^{63}$ Brown, supra note 49. Professor Brown states:

Both mediation and arbitration require specific skills for the impartial person or persons. For mediators, there is a particular need for the arts of listening, questioning, fact-finding, and interpreting the views of each party. The arbitrator needs all of that, plus the courtroom skills of a good judge. This starts with knowledge and experience in the rules of procedure and evidence and in substantive law. It may have to be supplemented by specialized knowledge or a firm determination to acquire the necessary learning. Arbiters should exclude bias, conflicts of interest, and personal misconduct toward the parties and their counsel. Anomalously, arbitrators who are experts or specialists in the substantive field of the dispute are seldom, if ever, impartial, but that is not ground for removal. Contrary to widespread opinion, there is no obvious match between the traits that constitute excellent judicial conduct as against those needed for arbitration or when compared with the skills appropriate for successful mediation.... The skill levels, substantive experience, and personal biases of the hearing officer (arbitrator or mediator) are seldom known to the litigants at the time of their selection. The designation and appointment of judges carries a much sounder opportunity to obtain quality and impartial services. The 


\section{E. Privacy and Confidentiality}

With private $A D R$, the parties can obtain a large measure of privacy and confidentiality. Often being a private proceeding, ADR allows businesses to resolve their disputes without creating a public record. ${ }^{64}$ For a business concerned about eroding public confidence in its products or services, any proceeding that allows it to resolve its disputes outside the public eye is attractive. ${ }^{65}$ Similarly, ADR is often attractive to a business concerned about being forced to reveal one or more of its trade secrets during litigation. ${ }^{66}$ Businesses may also seek to avoid creating a legal precedent that may later prove to be disadvantageous to them or their industry, and are thus drawn to ADR processes in which the likelihood of a successful appeal is small. ${ }^{67}$

choice of arbitrators is essentially one of self-appointment by the candidates with little or no verification, clearance, or appraisal. The parties seldom know the arbitrators and have no way to obtain knowledge of their skills, demeanor, bias, and reliability.

Id. at 758, 760 (footnotes omitted).

A 1997 joint study by Cornell University's Institute on Conflict Resolution and Price Waterhouse also found that "many in corporate America remain uncomfortable with the qualifications of arbitrators and mediators." Cornell University Business News (visited Nov. 4, 1999)<http://news.cornell.edu.business/ May97/ADRstudy.html>. See also Editorial, Mandatory ADR: Can We Talk?, supra note 52, at 321 (noting that even "ADR practitioners and supporters have long worried about problems posed by inadequately trained neutrals and lack of quality control procedures" and that the "rise of private dispute resolution services and the apparent willingness of some judges to direct parties to particular providers have rightfully exacerbated these concerns").

${ }^{64}$ See generally William H. Schroder, Jr., Private ADR May Offer Increased Confidentiality, NAT'L L.J., July 25, 1994, at C14.

${ }^{65}$ See Resnik, Failing Faith, supra note 47, at 538 ("[M]any defendants (and their attorneys) in products liability and antitrust cases ... now seem intrigued by $\mathrm{ADR}$ as a means of protecting themselves from negative publicity and from outcomes they have disliked.").

${ }^{66}$ See Arnold, supra note 43, at 34 ("Because with ADR you can have a major measure of confidentiality from competitors."); Cohen, supra note 43 , at 4 ("[Businesses] also appreciate the privacy and confidentiality factors since most businesses do not want their competitors, customers, suppliers or franchisers to know about their lawsuits.").

${ }^{67}$ See Brown, supra note 49, at 762 (discussing the common standards for reviewing and challenging an arbitrator's legal and factual findings_-"manifest disregard of the law," "arbitrary and capricious," and "completely irrational"- and 
However, many businesses are discovering that the touted privacy and confidentiality of private $A D R$ is by no means a sure thing and can be problematic. For example, with respect to mediation, judges who have ordered a case to mediation often request a status report from the mediator in order to determine which party is bargaining in good faith and which is footdragging. ${ }^{68}$ In other cases, prosecutors may call the mediator or arbitrator to testify. ${ }^{69}$ There are also situations in which a company's decision to seek refuge in the privacy of ADR backfires. Consider a large company who has been sued by multiple customers. Assume that the company believes that all of the cases are without merit, but agrees to mediation, and for economic, publicity, and risk considerations agrees to pay ten cents on the dollar to settle the first ten cases. As part of its strategy in mediating the eleventh case, the company may wish to use this data to its advantage and as evidence of what the case is "worth." However, depending upon the confidential settlement terms that were reached and agreed to during the first ten mediations, the company and its counsel may have failed to think things through and may have inadvertently waived the ability to utilize such information in the eleventh case. ${ }^{70}$

\section{F. The Advertised Ability of ADR to Provide "Win-Win" Business Solutions and Preserve Business Relationships}

Another touted advantage of private ADR is its ability to offer "winwin" solutions that courts cannot provide in a business dispute. ${ }^{71}$ If, for

discussing how these standards are very difficult to satisfy). In California, it has become virtually impossible to set aside an arbitrator's award because the state legislature amended the state arbitration act to provide that an arbitrator's award stands even where an error exists on the face of the award. See id.

${ }^{68}$ See Michael Higgins, In the Spirit of Mediation, A.B.A. J., Mar. 1998, at 94.

${ }^{69}$ See id.

${ }^{70}$ One of the authors was involved in a recent mediation proceeding that posed a similar issue for the opposing party and its counsel.

${ }^{71}$ See, e.g., Arnold, supra note 43, stating:

[W] ith mediation you can enjoy win-win creative business alternative solutions that courts simply cannot grant. Let me give you an example. A patentee sued for infringement of its patent on a catalytic cracking process. The patentee's analysis was:

- It had a one in three chance of winning the court trial.

- If it won, the win would be worth $\$ 35,000,000$ or thereabouts.

- It was risking about $\$ 1,500,000$ in litigation costs chasing that $\$ 35,000,000$. 
example, a plaintiff's prumary goal is to obtain an apology from a defendant as opposed to monetary compensation, ADR is probably the way to go. ${ }^{72}$ ADR is frequently viewed as being less hostile than traditional litigation, ${ }^{73}$ thereby allowing businesses to better preserve ongoing relationships. ${ }^{74}$ Yet these claimed benefits are often overly simplistic, presumptuous, and even misleading. There is also nothing that prevents an attorney in traditional

- A guy can get rich betting 1.5 to get 35 at one-to-three odds.

- Therefore, go for it.

What was the win-win business alternative solution that we found to resolve this dispute? The accused infringer offered to sell to the patentee its next 10 years of catalyst requirement at $10 \%$ off the going price. This translated into a $\$ 10,000,000$ present value to the patentee. The patentee also saved $\$ 1,000,000$ in litigation costs. The patent, which we estimated stood a $60 \%$ chance of being held invalid or not enforceable, was not put at nsk. At that time we put a $\$ 4,000,000$ value on removal of the patent from risk. So the total value to the patentee of the proposed offer of settlement was estimated at about $\$ 15,000,000$. At one to three odds you don't risk $\$ 15,000,000$ chasing only $\$ 35,000.000$. What about the accused infringer? It had surplus plant capacity, would not have any increased capital, sales or G\&A expense because of its making this big new sale to a new customer. The infringer's incremental profit on the new sales projected out to a $\$ 15,000,000$ present value to the infringer. $\$ 15,000,000$ value to each party? That's what you call a win-win solution.

Id. at 34 .

72 See, e.g., Andrew Pollack, Japanese Suits on H.I.V-Tainted Blood Settled. N.Y. TIMES, Mar. 15, 1996, at A3 ("Some plaintiffs have sard they wanted apologies from the Government and the companies as much as they wanted compensation.").

${ }^{73}$ See Cohen, supra note 43 , at 4 ("[ADR] also can preserve business relationships which a more traditional form of suit can destroy.").

${ }^{74}$ See Arnold, supra note 43, at 33-34 ("[W]ith ADR you can preserve ongoing relationships, licensor-licensee relationships, joint venture relationships, that litigation inevitably destroys."). The following quote from one in-house counsel who was the subject of Lande's study displays a common attitude among businesspersons on this issue:

Many of our businesses are with an industry in which it's primarily a customer-dominated market. In other words, if I have a dispute with a car company, the overnding consideration is the long-term relationship. Whether we win, lose, or draw, the economics, how strong our case 1s-none of that matters.

Lande, supra note 46, at 19 (quoting from a Jan. 22, 1994 interview with an inhouse counsel). 
litigation from exploring and implementing "win-win" solutions. ${ }^{75}$ In fact, a well-trained attorney does so and skillfully uses the tools and leverage of the court system to attain that goal as quickly as possible for his or her client. ${ }^{76}$ Moreover, scholars such as Owen Fiss, Marc Galanter, and Mia Cahill have argued that many disputes involve such important issues that they should be litigated and that the "feel-good" results of ADR are often inferior to those obtained in traditional litigation. ${ }^{77}$

\section{Changes IN How Courts SERVICE Business Disputes}

While there is disagreement about whether a "litigation explosion" has occurred, ${ }^{78}$ there is little doubt that many people, including many of our own courts and judges, perceive that one has occurred ${ }^{79}$ Our judiciary has attempted to cope with this perceived increase in its workload primarily through the following tools: (1) managerial judging; (2) the process of "self-bureaucratization"; (3) the forcing of business cases into some form of ADR (often against the parties' will); and finally, (4) through the increased use of vacatur, selective publication and the adoption of nocitation rules, depublication, and filings under seal and confidential settlements. As shown below, for the businesses that do decide to enter into

${ }^{75}$ See Arnold, supra note 43. Arnold's example is in reality one that highlights the creativity of the remedy and legal counsel rather than the failings of the court system.

${ }^{76}$ The following is a common example in traditional litigation: One party sends out a series of document requests, deposition notices and interrogatories with a settlement offer. The settlement offer is timed to expire shortly before the discovery is due. This strategy can and often does serve as an effective impetus to get the parties to sit down, communicate and resolve the case.

${ }^{77}$ See Fiss, supra note 6; Marc Galanter \& Mia Cahill, "Most Cases Settle": Judicial Promotion and Regulation of Settlements, 46 STAN. L. REV. 1339 (1994) (arguing that from a substantive standpoint, settled resolutions are not necessarily superior to litigated ones).

${ }^{78}$ See supra notes 44-49 and accompanying text.

${ }^{79}$ See supra note 46 and accompanying text. For authorities discussing the judiciary's perception of a litigation explosion, see Macklin Fleming, Court Survival in the Litigation Explosion, 54 JUDICATURE 109 (June-July 1970); DANIEL J. MEADOR, APPELLATE COURTS: STAFF AND PROCESS IN THE CRISIS OF VOLUME-ANAPPELLATE JUSTICE PROJECTOFTHENATIONAL CENTERFOR STATE COURTS 7-9 (1974); Robert H. Bork, Dealing with the Overload in Article III Courts, 70 F.R.D. 78, 231 (1976); Nancy Levit, The Caseload Conundrum, Constitutional Restraint and the Manipulation of Jurisdiction, 64 NOTRE DAMEL. REV. 321 (1989). 
the traditional court system, these tools amount to yet another level of privatization, thereby further distorting and thwarting the growth of our common law.

\section{A. Managerial Judging}

Professor Judith Resnik has written extensively about what she calls "managerial judging"-where judges become involved in the pretrial management of the case to try and relieve perceived court congestion (e.g., ruling on discovery disputes, deciding joinder issues, conducting pretrial conferences, settlement conferences, and the like).$^{80}$ This type of judging poses several dangers. First, a deeper involvement by judges in the pretrial phase of the case may compromise their independence and prematurely cause them to favor one side or position in the dispute, in turn impacting the quality of their deliberations. ${ }^{81}$ Second, and more importantly for the purposes of this article, managerial judging undercuts the obligation and requirement that judges act in public and formally record the reasons behind what they do. ${ }^{82}$

The following is an example of the second problem. In the past, a young attorney who wanted to learn how a particular judge handled pretrial matters (e.g., discovery motions) could walk over to the courthouse and spend the morning in the gallery of the judge's courtroom observing the judge ruling on various law and motion matters. But now this is becoming more and more difficult to accomplish. Today, it is not uncommon for the case to be called and the parties' counsel to be led into the judge's private chambers (or a conference room) to sit down and discuss the case with the judge (or a discovery referee or judge pro tem). With no court reporter present, the matter is argued and decided. This same routine is then repeated for every case on the calendar. ${ }^{83}$ Relatedly, and perhaps even more disturbingly, today's courts and judges are often evaluated not for the quality of their decisions (e.g., how often they are appealed and reversed), but for their ability to move cases along and clear the docket. ${ }^{84}$ While the

${ }^{80}$ See Resnik, Managerial Judges, supra note 47; Resnik, Failing Faith, supra note 47. See also Rubin, supra note 30.

${ }^{81}$ See Resnik, Managerial Judges, supra note 47.

${ }^{82}$ See id.

${ }^{83}$ This has been the authors' experience, particularly in California's state court system.

${ }^{84}$ For example, the California Judicial Council publishes time-on-the-docket statistics for some of its courts. See JUDICIAL COUNCIL OF CAL., JUDICIAL COUNCIL 
impact of this management philosophy on the development of our contemporary body of commercial law is difficult to measure, we submit that it is more deleterious than beneficial.

\section{B. The Bureaucratization of the Judiciary}

We have also witnessed an increase in the size of the judiciary and its support staff (e.g., magistrates, special masters, judge pro tems, discovery referees, law clerks, staff attorneys, and the like), as well as an increase in judges' reliance on that staff..$^{85}$ Owen Fiss, Joseph Vining, and Judge Alvin Rubin refer to this development as the "bureaucratization of the judiciary. ${ }^{186}$ When judges delegate responsibility for initially assessing or deciding portions of a case to their support staff, they diminish their own level of personal responsibility for their decisions, which in turn leads to greater anonymity in judging. ${ }^{87}$ This results in the impression that these decisions have not been rendered or written by an individual with an identity of their own, but are instead the product of an impersonal institution. ${ }^{88}$ The downside of this impersonalization is that it gives businesses another reason to flee the court system for private ADR, thereby further distorting the growth of our commercial precedent. ${ }^{89}$

\section{Courts Forcing Business Cases into ADR}

The problem is not just a case of businesses wanting to avoid the traditional court system. Our courts have made the conscious policy decision to divert business cases into ADR in order to conserve judicial

REPORT ON COURT STATISTICS (1997). Inevitably, these statistics become ammunition in various political and public policy battles.

${ }^{85}$ See Owen M. Fiss, The Bureaucratization of the Judiciary, 92 YALEL.J. 1442 (1983); JOSEPH VINING, THE AUTHORITATIVE AND THE AUTHORITARIAN 51-57 (1986); Rubin, supra note 30. See also, Reuben, supra note 52, at 56 (noting the increased use of discovery referees in both state and federal courts); Kenneth $R$. Feinberg, Creative Use of ADR: The Court-Appointed Special Settlement Master, 59 ALB. L. REV. 881 (1996) (discussing the burgeoning use of court-appointed special settlement masters).

${ }^{86}$ Fiss, supra note 85 , at 1442 ; see also Vining, supra note 85 , at 6; Rubin, supra note 30.

${ }^{87}$ See Fiss, supra note 85 ; Vining, supra note 85.

${ }^{88}$ See Vining, supra note 85; Rubin, supra note 30, at 653.

${ }^{89}$ See, e.g., Rubin, supra note 30 , at 653 (suggesting that delegation to judicial staff will "[i]n the long run . . . lead to less respect for judicial decisions"). 
resources. ${ }^{90}$ Thus, for the company that does opt into the court system to have its "day in court," it is likely to find itself entangled in the very form of dispute resolution-ADR - that it sought to avoid from the beginning. In California, it has reached the point where, if the court learns that the two disputing businesses in a lawsuit have money and resources, they are ordered into some form of ADR (usually mediation) and are thereby stalled on the way to trial. ${ }^{91}$ Thus, even though business tax dollars help pay for

${ }^{90}$ While court use and promotion of ADR was not unheard-of prior to the 1970s, the 1976 Pound Conference on the Causes of Popular Dissatisfaction with the Courts (co-sponsored by Chief Justice Warren Burger, the Judicial Conference of the United States, and the American Bar Association) was the first major push to consider alternative ways to inexpensively and more efficiently obtain justice in the courts. See Griffin Bell, Improving the Administration of Justice, NIDR FORUM, Winter 1992, at 5; Deborah R. Hensler, A Glass HalfFull, a Glass HalfEmpty: The Use of Alternative Dispute Resolution in Mass Personal Injury Litigation, 73 TEX. L.REV. 1587, 1592(1995) (commenting on the Pound Conference); R. William Ide III, ADR: A Giant Step Toward the Future, DISP. RESOL. J., Dec. 1993, at 20 (discussing the effects of the Pound Conference). Following the Pound Conference, the use of ADR by courts has only accelerated. See Patrick Fn'Piere \& Linda Work, On the Growth and Development of Dispute Resolution, 81 KY. L.J. 959, 962-63 (1993) (discussing the growth and development of ADR in both the state and federal courts). See also Rhonda McMillion, Expanding ADR Options, A.B.A. J., June 1998, at 98 (noting that Congress has recently been urged to enact more legislation to encourage the federal courts to make greater use of ADR).

91 This has been the authors' experience on numerous occasions in both California's state and federal court systems. Even when the parties object to being sent to voluntary or involuntary ADR, it often does little good. The courts usually do not want to hear such objections. See also Stephen P. Younger, Effective Representation of Corporate Clients in Mediation, 59 ALB. L. REV. 951, 951-52 (1995) ("With increasing frequency, our courts are encouraging litigants to use... (ADR) procedures-such as mediation, early neutral evaluation, binding arbitration and summary jury trial-to clear up overburdened court calendars."); William K. Slate II, Arbitration Comes of Age, AM. LAW., May 1995, at 8 ("[S] tate and federal courts are now formally urging attorneys to turn to dispute resolution services for cases that do not, per se, require a judge."); Jacqueline M. Nolan-Haley, Court Mediation and the Search for Justice Through Law, 74 WASH. U. L. Q. 47 (1996) ("Within the last fifteen years, in both state and federal courts, litigants have often been required to attend [an ADR] session before they will be allowed to be heard by a judge."). Id. at 48-49 ("[C]ourts have shown increased interest in [ADR's] potential as an official settlement process. As [ADR] programs are institutionalized in court, litigants find themselves directed off their original course of seeking justice through law."). Id. at 52; Judith S. Kaye, Business Dispute Resolution-ADR and Beyond: An Opening Statement, 59 ALB. L. REV. 835, 837-38 (1995) (noting 
the court system, courts have sent a clear message that such judicial welfare is reserved for other types of cases; namely, criminal cases, family law cases, civil rights cases, and the like. Again, while the impact of this diversion process on our contemporary body of commercial law is difficult to measure, we submit that it is more harmful than beneficial.

\section{Vacatur, Selective Publication and No-Citation Rules, Depublication, and Filings Under Seal and Confidential Settlements}

Another means that the courts have seized upon to address the perceived workload problem has been to increase the use of vacatur, selective publication, the adoption of no-citation rules, depublication, filings under seal, and confidential settlements. As shown below, each of these procedures is a form of "privatization"92 that further "subtracts" from our body of commercial law.

\section{Vacatur}

One development that has recently become the subject of robust debate is the increasing use of vacatur, where, after a trial court reaches a decision and issues a judgment, the parties reach a private settlement rather than pursue further appeals. As a condition of their settlement, the parties request that the appellate court vacate the lower court's prior judgment. ${ }^{94}$

that even "at the appellate level just about every state intermediate appellate court and many federal appellate courts offer or require pre-argument submission to a third-part neutral to narrow and settle civil appeals"); Jerrold J. Ganzfried, Bringing Business Judgment to Business Litigation: Mediation and Settlement in the Federal Court of Appeals, 65 GEO. WASH. L. REV. 531 (1997) (noting the use and promotion of settlement by federal appellate courts as part of the appellate process).

${ }^{92}$ For example, Judith Resnik notes that procedures like vacatur can be seen as a "form of alternative dispute resolution." See Judith Resnik, Whose Judgment? Vacating Judgments, Preferences for Settlement, and the Role of Adjudication at the Close of the Twentieth Century, 41 UCLA L. REV. 1471, 1505 (1994) [hereinafter Resnik, Whose Judgment?].

${ }^{93}$ Slavitt, supra note 24, at 109 ("Our system of precedent has become subtractive as well as additive. Like a sculpture, it is shaped as much by what is removed as by what is added.").

${ }^{94}$ A detailed discussion and analysis of vacatur is beyond the scope of this Article. However, for a good presentation on vacatur, its history, usage rate, advantages and disadvantages, scope, and the debate surrounding its use, see Slavitt, supra note 24; Resnik, Whose Judgment?, supra note 92; Stephen $\mathrm{R}$. 
Vacatur not only erodes the public's confidence in the courts, ${ }^{95}$ but it also prevents the use of judgments for collateral estoppel purposes, diminishes the stare decisis value of judgments, and most importantly, alters the shape and development of our business and commercial precedent. ${ }^{96}$

\section{Selective Publication and the No-Citation Rule}

The decision by many court systems to selectively publish certain decisions is another form of privatization, ${ }^{97}$ largely motivated by workload and shelf space concerns regarding the burgeoning quantity of case decisions. ${ }^{98}$ But, as with vacatur, selective publication has resulted in a

Barnett, Making Decisions Disappear: Depublication and Stipulated Reversal in the California Supreme Court, 26 LOY. L.A. L. REV. 1033 (1993); Henry E. Klingeman, Settlement Pending Appeal: An Argument for Vacatur, 58 FORDHAM L. REV. 233 (1989).

${ }^{95}$ In Neary $v$. Regents of the University of California, Justice Joyce Kennard of the California Supreme Court wrote in her dissent that "Public respect for the courts is eroded when this court decides that a party who has litigated and lost in the trial court can, by paying a sum of money sufficient to secure settlement conditioned on reversal, purchase the nullification of the adverse judgment."Neary v. Regents of Univ. of Cal., 834 P.2d 119, 127 (Cal. 1992).

${ }^{96}$ See Slavitt, supra note 24, at 133-34. See also Resnik, Whose Judgment?, supra note 92 , at 1500 .

[I] $f$ one believes that an important purpose of litigation is to generate information and law for the benefit of third parties and the public in general, then objection should be made not only to the practice of vacatur on consent but also to the host of other procedural developments that promote settlement and other forms of alternative dispute resolution less accessible Id. to the public than is adjudication.

${ }^{97}$ Again, a detailed discussion and analysis of selective publication is beyond the scope of this Article. However, for a presentation on selective publication, its history, usage rate, advantages and disadvantages, scope, and the debate surrounding its use, see Slavitt, supra note 24; Gerald F. Uelmen, Publication and Depublication of California Court of Appeal Opinions: Is the Eraser Mightier than the Pencil?, 26 LOY. L.A. L. REV. 1007 (1993) [hereinafter Uelmen, Publication and Depublication]; William L. Reynolds \& William M. Richman, The NonPrecedential Precedent-Limited Publication and No-Citation Rules in the United States Court of Appeals, 78 COLUM. L. REV. 1167 (1978).

${ }^{98}$ See generally Slavitt, supra note 24, at 123 ("[J]udges do not have enough time and resources to analyze, research, and write each opinion to the extent necessary for it to become part of the system of published law."); Reynolds \& 
significant loss of available contemporary cases to use as a guide in resolving similar disputes. ${ }^{99}$ An additional concern raised by selective publication is that a court, knowing that it is not going to certify a case to be published, may not devote the same amount of energy to its decision. ${ }^{100}$

Richman, supra note 97, at $1183 \mathrm{n} .95$ (estimating that, based on records kept by seven Third Circuit judges, judges spend approximately $30 \%$ of their time writing opinions); Charles E. Carpenter, Jr., The No-Citation Rule for Unpublished Opinions: Do the Ends of Expediency for Overloaded Appellate Courts Justify the Means of Secrecy?, 50 S.C. L. REV. 235, 243, 249 (1998) (noting that "[t]he real reason for [the selective publication and] no-citation rule is overload on the appellate courts" and that "[f]ewer published decisions mean fewer volumes for libraries to purchase").

${ }^{99}$ See Hinderks \& Leben, supra note 15 , at 158 (noting that over $60 \%$ of federal circuit court decisions are not published); Gerald F. Uelmen, Losing Steam, CAL. LAW., June 1990, at 33, 43 [hereinafter Uelmen, Losing Steam]; Philip L. Dubois, The Negative Side of Judicial Decision Making: Depublication as a Tool of Judicial Power and Administration on State Courts of a Last Resort, 33 VILL. L. REV. 469, 488 (1988) (pointing out that less than $15 \%$ of appellate decisions in California are certified for publication and of that fifteen percent, the California Supreme Court orders an additional $10 \%$ depublished). Ironically, Judge Richard Posner notes:

Despite the vast number of published opinions ... judges will confess that a surprising fraction of ... appeals are difficult to decide, not because there are too many precedents but because there are too few on point.

RICHARD A. POSNER, THE FEDERAL COURTS: CRISIS AND REFORM 123 (1985) (emphasis added). Similarly, Howard Slavitt writes:

Selective publication suppresses precedent that would help courts decide future cases. In addition, even if selective publication saves time, it distorts the shape of precedent. Lawyers use precedent to evaluate how courts apply the law across a range of cases as much to identify what a precise rule of law is. One cost of saving time, then, is that it leaves the law unclear and may ultimately lead to more litigation to clarify the law. The long-term costs of distortion, therefore, may outweigh any short-term efficiency of savings .... By making the law more certain, it also allows individuals to structure their affairs to avoid disputes and litigation.

Slavitt, supra note 24, at 126, 140 (footnotes omitted).

${ }^{100}$ See Slavitt, supra note 24, at 123-24 (footnotes omitted). Slavitt states: When a judge knows ahead of time that an opinion will not be published, she can save time. First, the judge does not need to recite carefully the facts of the case because the parties are already familiar with them. Second, it is unnecessary to rehearse all of the arguments; the judge is able to focus the opinion on the dispositive issues. Third, the judge need not spend as much time eliminating vague language that other litigants may attempt to expand 
The selective publication problem is further aggravated by its sometime companion, the no-citation rule. ${ }^{101}$ However, if unpublished opinions are

in later cases. Because unpublished opinions serve no future purpose, judges need only provide a minimal indication of the reasoning that a fully explicated opinion would have followed.

Id. See also Carpenter, supra note 98, at 251 (noting that "if judges know that their opinions are not citable and that they will not have to sign the opinions, the same 'quality control' pressures will not be in place"). However, Anthony Kronman, Dean of Yale Law School, strongly criticizes this shortcut:

[O]pinion-writing disciplines the imagination. It is one thing to reach a tentative conclusion in a case, but something very different to write an opinion defending it. The search for the right words to support a judgment one has provisionally formed often stirs up new objections and compels the reexamination of earlier beliefs. A judge may feel that he has decided a case and is finished with it. But when he attempts to justify his decision in writing, he will be forced to reenact the drama of the original conflict in his imagination, taking first one side and then the other in an effort to anticipate the strongest arguments that might be made against his own earlier position and the best responses to them. Writing judicial opinions imposes on the writer a duty of responsiveness that can be met only by giving each side to a dispute its due, by entertaining every claim in its most attractive light, and that in turn demands a special effort of imagination. The discipline of opinion-writing is thus a goad to the imagination, and the greater the distance of the writer from the original conflict in a case, the more valuable this discipline becomes as a guard against the relaxation of his imaginative powers: which is why it is especially needed at the appellate level.

In many appellate courts, however, this discipline is weaker today than it has been in the past. In part this is due to procedural changes in court practice that permit more cases to be decided with no opinion or only an unpublished one-changes intended to increase the number of disputes that a court can decide in a given period of time. But a more important cause of the weakening of this discipline has been the growing tendency of appellate judges to work by editing draft opinions prepared for them by their clerks instead of writing opinions themselves... [E]diting does not in general make as strong a demand on the imagination as original composition.

ANTHONY T. KRONMAN, THE LOST LAWYER: FAILING IDEALS OF THE LEGAL PROFESSION 330-31 (1995) (footnotes omitted).

${ }^{101}$ See Carpenter, supra note 98 , at 236. See generally Hinderks \& Leben, supra note 15 (noting that no-citation rules are just what the name implies-they prohibit the citation of unpublished opinions). 
to be treated in a manner consistent with the common law model, then they should be citable as binding authority. ${ }^{102}$

\section{Depublication}

Many higher appellate courts are now depublishing certain decisions because they disagree with a lower court of appeal over a portion of its reasoning. ${ }^{103}$ As with vacatur and selective publication, depublication is form of privatization that has resulted in a loss of available contemporary cases to use as a guide in resolving similar disputes. For example, as earlier noted, the California Supreme Court depublishes more appellate opinions each year than it publishes opinions of its $\mathrm{own}^{;}{ }^{104}$ further, less than fifteen percent of appellate decisions in California are certified for publication, and, of that fifteen percent, the California Supreme Court orders an additional ten percent depublished. ${ }^{105}$

${ }^{102}$ See Carpenter, supra note 98, at 240 ("If unpublished opinions are to be treated in the traditional common law fashion, then they constitute a source of the first rank; that is, binding authority within the jurisdiction of the deciding court. These unpublished opinions should be citable if they are binding authority.").

${ }^{103}$ As with vacatur and selective publication, a detailed discussion and analysis of depublication is beyond the scope of this Article. For a presentation on depublication, its history, usage rate, advantages and disadvantages, scope, and the debate surrounding its use, see Barnett, supra note 94; Dubois, supra note 99; Joseph R. Grodin, The Depublication Practice of the California Supreme Court, 72 CAL. L. REV. 514 (1984); Slavitt, supra note 24; and Uelmen, Publication and Depublication, supra note 97.

${ }^{104}$ See Uelmen, Losing Steam, supra note 99, at 43-44.

${ }^{105}$ See id. at 44; Dubois, supra note 99 . Related to the vacatur, selective publication, no-citation, and depublication problems is the increased issuance of appellate decisions "without comment" and the decreased use of oral argument in appellate cases. Both of these tactics distort precedent. See William C. Smith, Big Objections to Brief Decisions, A.B.A. J., Aug. 1999, at 34, 36 (noting that "[1]ast year, the federal appeals courts disposed of 25,020 appeals on the merits. About six percent of the total were disposed of without comment, meaning the court did not expound the law as applied in the case, or did not explain the reasons for the ruling"); Stephen R. Barnett, The Death of Oral Argument, CAL. LAW., June 1990, at 45,46 (noting how the California Supreme Court votes on cases before oral argument and "[b]y the time of oral argument, the shooting is all but over"); Carpenter, supra note 98, at $255 \mathrm{n} .55$ (noting the "increasingly frequent cases where the court hears no oral argument and issues an unpublished opinion based solely on the briefs"). 


\section{Filings Under Seal and Confidential Settlements}

Typically, pretrial activity is not accessible to the public. ${ }^{106}$ This is certainly true with respect to most pretrial discovery. ${ }^{107}$ Yet, in spite of this fact, there is a "growing tendency" throughout the courts, "especially in commercial cases, for litigants to agree to seal documents produced during the discovery process as well as pleadings and exhibits filed with the court" 108 and to keep settlements confidential. ${ }^{109}$ This tactic, however, not only eliminates precedent, but also precludes third parties from obtaining such information ${ }^{110}$ and imposes substantial costs on future litigants who may not know of the underlying wrong. ${ }^{111}$ Or, even if these other litigants are aware of the wrong, they must proceed to conduct expensive discovery to prove once again that a wrong occurred. ${ }^{112}$

${ }^{106}$ See Resnik, Whose Judgment?, supra note 92, at 1493 n.84 ("Courts have generally interpreted the common law ... right of access to courts to apply, in civil cases, [only] to pleadings, motions and the documents presented in support of them, exhibits submitted at trial, and court transcripts of hearings, all of which are presumptively open to the public."). See generally Arthur R. Miller, Confidentiality, Protective Orders, and Public Access to the Courts, 105 HARV.L. REV. 427 (1991).

${ }^{107}$ See Resnik, Whose Judgment?, supra note 92, at 1493 n.85.

108 Nault's Auto Sales, Inc. v. American Honda Motor Co., 148 F.R.D. 25 (D.N.H. 1993) (criticizing the seemingly unchecked sealing of pleadings).

${ }^{109}$ For an insightful account and discussion of this topic, see Ralph Nader's and Wesley Smith's book "No Contest." NADER \& SMITH, supra note 57, at 60-99. See also John Gibeaut, Secret Justice, A.B.A. J., Apr. 1998, at 50; Resnik, Whose Judgment?, supra note 92, at 1493-94.

${ }^{110}$ Nader and Smith remind us that "information is power" and that "[i]n order for people to make informed decisions about how they will conduct their lives, about which products to purchase and which to avoid, about which companies to patronize, and the like, they need access to information." NADER \& SMITH, supra note 57 , at 61 .

${ }^{111}$ See, e.g., id. at 60-75.

${ }^{112}$ See, e.g., id.; Sunshine in Litigation Act: Hearing on S. 1404 Before the Senate Subcomm. on Courts and Admin. Practice of the Senate Comm. on the Judiciary, 103d Cong., 2d Sess. (1994). Sybil Niden Goldrich, cofounder of Command Trust Network (an organization that provides information to women with breast implants), stated:

[T] he legal staffs of the manufacturers understood their power. They fought using a strategy that required each plaintiff to reinvent the wheel. They knew that an ailing woman could be coerced into unconscionable 


\section{THE INSTITUTIONAL PRACTICE OF LAW FURTHERING THE PRIVATIZATION OF BUSINESS DISPUTE RESOLUTION}

We have highlighted the fact that, in order for commercial precedent to develop and grow, business cases must enter (and remain in) the court system, they must be tried and their records kept public, verdicts must be rendered, appeals pursued, and appellate opinions published. Popular - perception would have us believe that today's lawyers are trying cases and putting that process in motion. ${ }^{113}$ However, this perception is not the reality for the vast majority of today's litigators. ${ }^{114}$ Most cases are resolved by negotiated settlements. ${ }^{115}$ Traditional litigation in the form of a trial and appeal is the exception. ${ }^{116}$ Professor Kevin McMunigal states this perfectly.

The last two decades have seen a population explosion in the legal profession, and much of the new manpower is employed exclusively in work related to lawsuits. These lawyers are usually not tral lawyers. They are called "litigators." Few of them have had jury expenence, and if they participate in a bench trial it would be as "second charr" to a tral lawyer. It is important to understand that the litigator is not simply a young lawyer

settlements. They fought until the cost of litigation increased to such a level that lawyers had to capitulate.

Id. See also Brian T. FitzGerald, Sealed v. Sealed: A Public Court System Going Secretly Private, 6 J. L. \& POL. 381 (1989) (arguing against sealing).

${ }^{113}$ To list a few examples from film and television: L.A. Law (NBC television broadcast commencing 1987); THE VERDICT (Twentieth Century Fox 1982); Ally McBeal (Fox television broadcast commencing 1998); A FEW GOOD MEN (Columbia 1993); KRAMER VS. KRAMER (Columbia 1979). Some book and novel examples include: SCOTT TUROW, PRESUMED INNOCENT (1987); HARPER LEE, TO KILL A MOCKINGBIRD (1960); JONATHAN HARR, A CIVIL ACTION (1995); TOM WOLFE, THE BONFIRE OF THE VANITIES (1987).

${ }^{114}$ See CHARLES W WOLFRAM, MODERN LEGAL ETHICS at 593 (1986) ("Most lawyers spend little time in courtrooms, and a large percentage spend their entire practice without litigating a case. The dominance of litigation in the public mind reflects history, not present reality.").

${ }^{115}$ See Kevin C. McMunigal, The Costs of Settlement: The Impact of Scarcity of Adjudication on Litigating Lawyers, 37 UCLAL.REV 833, 838-39 nn.15, 17-19 (1990) (and authorities cited therein).

${ }^{116}$ See $1 d$., see also Kleiner, supra note 6, at 90 ("Just a fraction of legal matters are ultimately resolved in court."). 
acquiring experience that will equip him to start trying cases. Litigators are now a separate specialty. There are many 50-year old litigators whose trial experience has been negligible. They are highly regarded in their specialty and conduct seminars attended by those who wish to improve their own skills as litigators. And they are in charge of training the new generation of litigators. ${ }^{117}$

\section{McMunigal continues:}

[Unlike the discovery lawyer] [t] he experienced trial lawyer understands the ultimate end of the discovery process. He knows that everything he does is directed to the single goal of convincing the judge or jury. When the experienced trial lawyer prepares a case, he never loses sight of the fact that he is structuring the case for trial. In a sense, he is constantly asking what do I need for the trial? how can I get it quickly? and how can I get the information without helping or instructing my adversary? ... .

All too often the discovery lawyer with little trial experience is uncertain and lacks direction. This is particularly so in large cases where the lawyer who prepares the case not only will not try it but may only be familiar with one small aspect of the case. In such a case the discovery tends to lack direction because the lawyer does not know where he is going or why he's doing certain things. More depositions are taken than needed. Witnesses are deposed who are not needed and who should not have been deposed at all. Objections and evasions are frequent because the discovery lawyer just isn't sure how the senior man will try the case and doesn't want to be criticized for not protecting the client.

The lawyer's lack of trial experience causes him anxiety and uncertainty. Because he is not confident all too often the tendency is to try to insure that absolutely nothing is left uncovered. The discovery goes on interminably as every conceivable stone is turned. The unfortunate result is misused discovery, overdiscovery, expensive discovery, and at times, harmful discovery. ${ }^{118}$

What is the reason for the advent of the "discovery lawyer?" Some suggest that it is the result of the "procedural opportunities created by the Federal Rules of Civil Procedure."119 It may also be due to the staffing

${ }^{117}$ McMunigal, supra note 115 , at 840.

${ }^{118}$ Id. at 870.

${ }^{119}$ Id. at 840. See also Resnik, Failing Faith, supra note 47, at 522 ("With the new procedural opportunities [created by the 1938 Federal Rules of Civil 
needs of large-scale litigation. ${ }^{120}$ Others suggest that the simultaneous decline in trial rates and increase in the number of lawyers has led to this new "specialty."121 However, we suggest an alternative reason: large corporate law firms, their current structure and organization, and their corresponding failure to properly train and mentor their junior attorneys for trial work. ${ }^{122}$

By way of background, in 1991, forty-seven percent of all lawyers in private practice were in tirms of twenty-one or more lawyers, including thirty-three percent in firms of fifty-one or more lawyers. ${ }^{123}$ Today this figure is undoubtedly higher. ${ }^{124}$ This is not to say that the influence of

Procedure] came a new set of lawyers, 'litigators,' who did their work (motions, depositions and interrogatory practice) during the pretrial process and who were to be distinguished from 'trial lawyers,' who actually conducted trials."). See generally Jonathan T. Molot, How Changes in the Legal Profession Reflect Changes in Civil Procedure, 84 VA. L. REV. 955 (1998).

${ }^{120}$ See McMunigal, supra note 115 , at 841 n.23. McMunigal notes:

Large scale, massive, multi-party litigation frequently involves extremely complex and detailed factual disputes. Such cases have spawned a generation of lawyers who have spent years engaged in reviewing documents, litigation motions about the scope of discovery and answering interrogatories. These discovery lawyers know the ins and outs of the Federal Rules of Discovery. But these discovery lawyers seldom try cases and, unfortunately, often do not know how to try a case effectively. Their Id. skills are not the skills of the experienced trial lawyer.

${ }^{121}$ See id. at 853-55 and accompanying notes.

${ }^{122}$ For an excellent discussion on the arrival, growth and transformation of the large corporate law firm, see MARC GALANTER \& THOMAS PALAY, TOURNAMENT OF LAWYERS: THE TRANSFORMATION OF THE BIG LAW FIRM (1991); KRONMAN, supra note 100, at 271-314. See also LINCOLN CAPLAN, SKADDEN: POWER, MONEY, AND THE RISE OF A LEGAL EMPIRE (1993) (detailing the history, development and rise to power of the Skadden law firm in New York).

${ }^{123}$ See BARBARAA. CURRAN\&CLARAN. CARSON, THELAWYER STATISTICAL REPORT: THE U.S. LEGAL PROFESSION IN THE 1990S 8 (1994). See also ROBERT GRANFIELD, MAKING ELITE LAWYERS 5 (1992) (reporting that half of UCLA Law School graduates in 1986 entered law firms employing more than 50 lawyers and that $14 \%$ of law school graduates entering private practice in 1987 did so with firms of 100 or more attorneys); GALANTER \& PALAY, supra note 122, at 46 (tracing the growth in large law firms from the 1950s to the 1990s).

${ }^{124}$ See Lewis A. Kornhauser \& Richard L. Revesz, Legal Education and Entry Into the Legal Profession: The Role of Race, Gender, and Educational Debt, 70 N.Y.U.L.REV. 829, 839 (1995) (noting that in the practice of law "there [has been] 
smaller law firms and solo practitioners on our body of commercial law is insignificant. Nonetheless, the reality is large corporate law firms handle the majority of legal work for most (if not all) major U.S. companies, and they exercise power and influence well beyond their numerical strength. Anthony Kronman points out:

[T] hese firms are elite institutions. They attract the best law school graduates, have the most powerful clients, and possess the greatest clout within the profession. They also make the most money. As a result, they exert a disproportionate influence on the practicing bar as a whole. Any basic change in the culture of the corporate firm, such as has occurred in the last twenty years, is therefore certain to have repercussions far beyond these firms themselves and to be felt in some measure by all those that stand below them in the hierarchy of power and prestige.

.... [T] he large corporate firm continues to exercise an influence, both within the profession and outside it, that far exceeds its numerical strength. ${ }^{125}$

In the past, the mentoring and training of junior lawyers to become skilled trial attorneys was an important part of the institutional structure of these firms. ${ }^{126}$ Today that is no longer the case. Despite their claims to the contrary, ${ }^{127}$ they have become driven by the "bottom

a marked shift to practice in larger settings"); Barbara A. Curran, American Lawyers in the 1980s: A Profession in Transition, 20 L. \& SOC'Y REV. 19 (1986) (indicating that lawyer demographics show an increasing trend of lawyer employment in group settings and a decline in solo practice).

${ }^{125}$ KroNMAN, supra note 100, at 272-73. See also Bryant G. Garth, Legal Education and Large Law Firms: Delivering Legality or Solving Problems, 64 IND. L.J. 433, 433 (1989) ("Large law firms are the most successful institutional component of the American legal profession according to the criteria of economic prosperity, proximity to the corridors of economic and political power, and the influence exerted on the legal profession generally.").

${ }^{126}$ For an excellent example, see PatrickJ. Schiltz, Legal Ethics in Decline: The Elite Law Firm, the Elite Law School, and the Moral Formation of the Novice Attorney, 82 MNN. L. REV. 705, 720-22 (1997) (detailing the mentoring and training Professor Schlitz received at his firm as a young attorney).

${ }^{127}$ See, e.g., CAPLAN, supra note 122, at 191-206 (suggesting that the Skadden firm's various pro bono activities, while touted as a way to give back to the community and provide legal training, were in reality a strategy by the firm to enhance its public image and thereby increase profits). 
line."128 The effective mentoring and training of their junior attorneys is no longer a priority. ${ }^{129}$

This development has manifested itself in a variety of ways, each of which has contributed to (and continues to contribute to) the advent of a generation of discovery lawyers who do not know how to try a business case. For example, the compensation of partners in these firms (and decisions about who makes partner) focuses almost exclusively on the business and revenue that the partner generates. ${ }^{130}$ The partner who brings in business and is able to keep as many associates as possible busy in his or her practice group can expect to be handsomely rewarded by the firm. The partner who takes a daily hands-on approach to the legal work of a business client and uses that process to train and mentor the firm's junior lawyers is unlikely to fare as well. ${ }^{131}$ The impact of this management

${ }^{128}$ See John J. Curtin, Jr., Civil Matters, A.B.A. J., Aug. 1991, at 8 ("The law is edging ever closer to being a business rather than a profession, a development which emphasizes the bottom line above all other concerns."); GALANTER \& PALAY, supra note 122, at 2-3 ("[Although] laments about commercialization and the loss of professional virtue have recurred regularly for a century . . . there is something different this time around. The present 'crisis' is the real thing.") (footnote omitted); GLENDON, supra note 1, at 6 (noting the increasing prevalence of the view "that law is a business like any other; and that business is just the unrestrained pursuit of self-interest"); Carl T. Bogus, The Death of an Honorable Profession, 71 IND. L.J. 911, 913 (1996) ("[T] he practice of law is suffering from increased commercialization."); NADER \& SMITH, supra note 57, at 233 ("[M]oney seems to drive the corporate legal culture, creating a bottom-line mentality under which what is best for the financial interests of the law firm is confused with what is best for the legal needs of the client.").

${ }^{129}$ See Schiltz, supra note 126, at 739-46. See also Debra Baker, Cash-andCarry Associates, A.B.A. J., May 1999, at 40-44 (detailing the lack of mentoring and training for today's junior litigators). In the March 1989 issue of the California Lawyer, it was reported that many California firms are using outside consultants for training in trial skills. See Paul D. Freeman, Teach the Associates Well, CAL.LAW., Mar. 1989, at 77. However, McMunigal suggests that while the articulated reason for using such consultants is "efficiency," an alternative explanation may be that even the partners in today's law firms lack the necessary trial skills to provide such training. McMunigal, supra note 115, at 852 n.82. See also NADER \& SMITH, supra note 57, at 251 ("Partners will not 'waste time' training associates because it takes away from billable work. That leads to an atmosphere where money is the most important thing.").

${ }^{130}$ See, e.g., GALANTER \& PALAY, supra note 122, at 52-53.

${ }^{131}$ In working for and litigating against large corporate law firms, the authors have seen many such examples. Interestingly, there are even cold, calculating 
philosophy and institutional structure on mentoring and training is obvious. Second, the associates in these firms are under tremendous pressure to bill hours ${ }^{132}$ and at the same time bring in new business. ${ }^{133}$ They are also expected to hit the ground running to justify their high starting salaries. ${ }^{134}$ There is, quite simply, no time for junior attorneys to be mentored and trained in a personal, deliberative, and thoughtful way. Third, the increased lateral movement of attorneys has caused many corporate law firms to view junior attorneys as "dispensable worker bees" rather than someone they should invest in and train to become quality trial lawyers. ${ }^{135}$ Finally, in an intensely competitive legal environment, many corporate law firms will not hesitate to try and lure clients away from competing firms; ${ }^{136}$ and time that

mathematical formulas that such firms use to measure profitability and performance. See, e.g., Ward Bower, Practice Management and Profitability (visited Jan. 2, 2000) <http://www.altmanweil.com/publications/articles/economic financial_managementefm3a.htm > (located on the website of Altman Weil, Inc., a global consulting firm to the legal profession). This web page contains a report listing and discussing a formula that measures law firm profitability based upon such factors as the ratio of associates to partners, the "blended" hourly billing rate, the number of client hours recorded, etc.

${ }^{132}$ See Schlitz, supra note 126, at 739-740. See also Carrie Menkel-Meadow, Culture Clash in the Quality of Life in the Law: Changes in the Economics, Diversification and Organization of Lawyering, 44 CASE W.RES.L.REV. 621, 62934 (1994) (discussing the large corporate law firm, and in particular its increased emphasis on "billable hours"); Terry Carter, Superstars or Falling Stars?, A.B.A. J., Aug. 1998, at 28 (putting the current billable hour "gold standard" at corporate law firms at 2400 hours per year); KRONMAN, supra note 100, at 281 (noting that many large firms "operate around-the-clock with a twenty four hour secretarial staff"); NADER \& SMTTH, supra note 57, at 235 ("Corporate attorneys in big firms 'are under intense pressure to bill as many hours as possible and are strongly motivated to maximize their hours by fair means or foul." ").

As McMunigal notes, such an institutional structure "may create pressures for lawyers to file meritless cases to generate hourly fee work in discovery and motion practice." McMunigal, supra note 115 , at 864 . He also notes that pretrial maneuvering, including discovery, has now become the "main event" in many lawsuits. Id. at 869.

${ }^{133}$ See Schlitz, supra note 126, at 741; NADER \& SMITH, supra note 57, at 251 ("Often, the lawyers who made partner weren't the skilled professionals but the best rainmakers, who know how to bill and work a cocktail hour to garner clients.").

${ }^{134}$ See Schlitz, supra note 126, at 743.

${ }^{135}$ See id. at 744.

${ }^{136}$ See id. at 741. 
a lawyer spends courting a competitor's client decreases the number of hours in a day available for providing or receiving mentoring and training.

Unfortunately, this focus and institutional structure distorts our system of commercial precedent. Among other things, the discovery lawyers that these firms grow and produce undoubtedly increase litigation expense, ${ }^{137}$ which in turn probably causes some businesses to flee the public court system and turn to private ADR to resolve their disputes. Further, because many discovery lawyers lack confidence in their trial skills, they may consciously (or subconsciously) seek out private $A D R$ in order to minimize their own stress or embarrassment. ${ }^{138}$ For the few discovery lawyers that do actually end up trying a business case, it is not uncommon to see a polluted trial court record subsequently presented to the court of appeal, ${ }^{139}$ thereby

${ }^{137}$ See supra notes 117-18 and accompanying text quote by Professor McMunigal.

${ }^{138}$ See McMunigal, supra note 115 , at 873 . McMunigal notes:

One frequently voiced claim for settlement is that the processes which lead to it take less of a psychological and emotional toll on the parties to [the] litigation. If this is true, then perhaps settlement may take less of a psychological and emotional toll on lawyers as well. Some litigators complain that their professional lives are consumed by conflict and negativism, that litigation is, at heart, a relentlessly destructive enterprise, dominated by efforts to find and exploit vulnerabilities in others, while tenaciously warding off similarly driven efforts by opponents. The pursuit of reasonable grounds for settlement can offer litigators a break from all this.

Id. McMunigal furthermore makes the point that when the number of civil trials declines, litigators' advocacy skills atrophy. This degeneration process in turn distorts not only the trial skills of litigators, but also the settlement process. In other words, litigators without adequate trial experience are less able to accurately evaluate cases and are more likely to settle out of fear of their own inadequacy. See id. at 855-62; see also G. Thomas Eisele, The Case Against Mandatory CourtAnnexed ADR Programs, 75 JUDICATURE 34, 40 (June-July 1991) (Judge Eisele notes that "lawyers with limited trial skills will ordinarily prefer a procedure that is less demanding.").

${ }^{139}$ See Warren E. Burger, Some Further Reflections on the Problem of Adequacy of Trial Counsel, 49 FORDHAM L. REV. 1, 1 (1980) ("[A] broad consensus has now emerged that a significant problem concerning the quality of a substantial number of lawyers' performances in the trial courts does indeed exist."); Malcom Richard Wilkey, A Bar Examination for Federal Courts, 61 A.B.A.J.1091, 1091 (1975) (commenting on the "inability of a startling percentage of lawyers to try a lawsuit"); Rubin, supra note 30, at 649 ("Today appeals involve records of thousands of pages and briefs arguing dozens of issues."). 
perhaps leaving an appellate court with no choice but to use the privatization tools of selective publication and depublication.

\section{ADDITIONAL DANGERS POSED BY THE PRIVATIZATION PROCESS}

Any mechanism that privatizes the resolution of business disputes thwarts our system of precedent and will have a significant impact on the business community and our society. But has the business community, those governing and advising them, or the judiciary, honestly, intelligently, and fairly evaluated and weighed the benefits of this privatization process against the harms? We submit that the answer is no. In addition to stunting the growth of our commercial precedent, the following are additional dangers presented by these privatization processes.

\section{A. The Loss of Information and Reduction of the Public Welfare}

As previously noted, one of the attractive features of private ADR is that certain things can remain private and confidential. ${ }^{140}$ However, this results in a significant amount of information that is difficult to track and lost to the public. ${ }^{141}$ Further, to the extent that public disclosures are made during the privatized process, they are often not tracked, memorialized and stored. ${ }^{142}$ There is already a scarcity of data and information available to scholars who study private ADR and the court system. ${ }^{143}$ The privatization of business disputes only adds an additional layer of fog that makes the meaningful study and analysis of such issues all the more difficult.

Moreover, if we are serious and sincere about protecting the public welfare, much of the information that is normally hidden by private ADR should be made available to the public. Take, for example, Whirlpool Corporation who, several years ago, entered into an agreement with State Farm Fire and Casualty Company that "established the process for resolving State Farm's subrogation claims against Whirlpool arising out of products sold by Whirlpool which allegedly caused property damage to

${ }^{140}$ See supra notes 64-67 and accompanying text.

${ }^{141}$ See Edward Brunet, Questioning the Quality of Alternate Dispute Resolution, 62 TUL. L. REV. 1, 13 (1987); Kevin R. Casey, Alternate Dispute Resolution and Patent Law, 3 FED. CIRCUIT B.J. 1, 5 (1993).

${ }^{142}$ See, e.g., Borzou Daragahi, Environmental ADR: Demand for Arbitration Raises Practical Concerns, N.Y. L.J., Sept. 8, 1994, at 5; Schroder, supra note 64, at $\mathrm{C} 14$.

${ }^{143}$ See supra note 52. 
State Farm's insureds."144 Whirlpool and State Farm agreed to remove all disputes from the public court system and resolve their disputes pursuant to mediation and arbitration. ${ }^{145}$ The companies streamlined discovery rules and eliminated outside lawyers from the process. ${ }^{146}$ The proceedings and all decisions were kept confidential, and thereby inaccessible to the plaintiff's bar. ${ }^{147}$

This arrangement is undoubtedly of great value and benefit to Whirlpool and State Farm. Nevertheless, there are compelling reasons why such agreements violate public policy and such information should be revealed. In a typical products liability lawsuit, for example, the negative effects of a product may not yet be known to the general public. ${ }^{148}$ At least in the court system, certain procedures must be followed before documents containing such vital information can be sealed. ${ }^{149} \mathrm{Also}$, if the need later arises and an adequate showing is made, such documents can be later unsealed for the public's perusal. ${ }^{150}$ Such institutional protections are completely lacking in the world of private ADR. Arthur Bryant of Trial Lawyers for Public Justice hits the mark on this important point:

[S]ecrecy subverts democracy itself.

....

Every day the papers are filled with disputes over whether our civil rights, securities, antitrust, product liability, environmental and other laws need to be changed. Wouldn't it be great if, in order to decide these and similar questions, the public, Congress and the president could actually know the facts? ${ }^{151}$

${ }^{144}$ Robert T. Kenagy, Whirlpool's Search for Efficient and Effective Dispute Resolutions, 59 ALB. L. REV. 895, 897 (1995).

${ }^{145}$ See id. at 898.

${ }^{146}$ See id.

${ }^{147}$ See id.

${ }^{148}$ See generally Edward J. Higgins, Gone But Not Forgotten: Manufacturers' Post-Sale Duties to Warn of Recall, 78 MicH. B.J. 570, 571 (1999) (discussing manufacturers' continuing duty to warn consumers about dangerous defects in products discovered after the product is placed into the stream of commerce).

${ }^{149}$ See, e.g., FED. R. CrV.P. 26(c)(6)-(7) (trade secret material can be sealed "for good cause" as "justice requires"). See generally Gibeaut, supra note 109.

${ }^{150}$ See 8 Charles AlaN WRIGHT ET AL., Federal PraCtiCE AND ProCEDURE $\S 2044.1$ (2d ed. 1994) ("Modification of Protective Orders"). See generally Gibeaut, supra note 109.

${ }^{151}$ Arthur H. Bryant, Letters, A.B.A. J., June 1998, at 10. 


\section{B. Widening the Gap Between the "Haves" and "Have-Nots"}

The publicly-supported judicial system has, at least as one of its announced goals, the desire to bridge gaps in resources between the parties and ensure that the proceeding is conducted on a level playing field. ${ }^{152} \mathrm{~A}$ good judge will often look out for the party who may be outmatched by a better funded or more talented opponent. If, for example, a young attorney is having difficulty properly framing an important question to a witness during a trial, it is not uncommon for the judge to suggest a more appropriate question to ask. ${ }^{153}$ But with private $\mathrm{ADR}$, the participants receive something very different. Third party neutrals do not normally assume such a protective role, especially if they were selected from an industry panel. ${ }^{154}$ Many sophisticated businesses and their corporate counsel know this fact and seek to use it to their advantage, primarily through mandatory

152 See JUDICIAL CONFERENCE OF THEUNITED STATES, LONG RANGE PLANFOR THE FEDERAL COURTS 71 (1995). It states:

Private forums should be encouraged, but the federal courts must not shed their obligation to provide public forums for disputes that need qualities that federal courts have traditionally provided, including at a minimum a neutral and competent decision-maker and the protection of weaker parties' access to information and power to negotiate a dispute.

See also Fiss, supra note 6, at 1077 ("We count, however, on the guiding presence of the judge, who can employ a number of measures to lessen the impact of distributional inequalities [between the parties].").

${ }^{153}$ Both authors have witnessed such assistance by judges in business cases at both the state and federal level.

${ }^{154}$ See Peter F. Blackman, Arbitration Suit Asserts Constitutional Arguments, NAT'L L.J., Feb. 27, 1995, at B1, B2; Richard C. Rueben, Reforming ADR, CAL. LAW., Feb. 1998, at 31; and Michele Marcucci, Freeing ADR, CAL. LAW., Feb. 1998, at 29, 70-75. Other areas of concern with respect to private ADR are the lack of an adequate record, the unchecked power of arbitrators, and the difficulty in challenging an arbitration award. See Bird v. Shearson Lehman/Am. Express, Inc., 926 F.2d 116, 123-24 (2d Cir. 1991) (Kearse, J., dissenting). Judge Kearse noted that AAA's commercial arbitration rules only require the arbitrator to put his or her award in writing, not to provide an explanation for the decision.

In 1988 congressional hearings on arbitration reform, a securities industry spokesman noted that arbitrators in the industry are regarded as being free to grant or deny awards without complying with applicable legal standards ... [The] arbitrators frequently made decisions that did not reflect legal standards but rather sought to do rough justice.

Id. at 124 (citation omitted). 
arbitration clauses. ${ }^{155}$ In short, while private $A D R$ is no doubt appropriate for certain disputes, we should not allow it to become a corporate tool for further widening the gap between the "haves" and "have-nots" in business. ${ }^{156}$

\section{A Reduction in the Power of the Courts}

Courts, like any institution, can only function properly if they have the respect and support of the people. However, as businesses make increasing use of private $A D R$, only certain types of cases may be left in the court system-namely, criminal, family law, civil rights, in pro per cases, and the like-thereby reducing the overall power of the courts in our society. ${ }^{157}$ Are

${ }^{155}$ The securities industry is notorious for doing this. In the past it has supported the system of specialist arbitration and even subsidized the cost of arbitration. See Susan Antilla, Brokerage Firms Steer Dissatisfied Customers Away From Court, but in Only One Direction, N.Y. TIMES, May 12, 1995, at A29. According to one observer, "Christians had a better chance against the lions than many investors and employees will have in the climate being created now." Margaret A. Jacobs \& Michael Siconolfi, Losing Battles: Investors Fare Poorly Fighting Wall Street-And May Do Worse, WALL ST. J., Feb. 8, 1995, at A1. See also Barbara Presley Noble, At Work: Attacking Compulsory Arbitration, N.Y. TMME, Jan. 15, 1995 , at F21.

Those with grievances and their representatives say the industry picks its arbitrators from a Wall Street 'old boy' network that is especially unlikely to look favorably on discrimination claims, requires little-to-no knowledge of employment law, conducts its operations in secret and explicitly tells its Id. mediators they neither have to follow the law nor explain their decisions.

${ }^{156}$ See Marc Galanter, Why the "Haves" Come Out Ahead: Speculations on the Limits of Legal Change, 9 L. \& SoC'Y REV. 96 (1974) (comparing the structural advantages of institutional litigants, or "repeat players," to "one-shot" litigants). Galanter notes that institutional litigants are typically those organizations that: (1) engage in frequent litigation; (2) are more concerned with long-range goals than with the outcome of a particular case; and (3) have the political and economic resources necessary to support their larger interests. See id. at 97-104. Galanter and others also note that businesses are the classic "repeat players" in the legal system and as such, are able to use their experience as "repeat players" to their advantage. See id.; see also Nancy H. Rodgers \& Craig A. McEwen, Employing the Law to Increase the Use of Mediation and to Encourage Direct and Early Negotiations, 13 OHIO ST. J. ON DISP. RESOL. 831, 839 (1998).

${ }^{157}$ See David Luban, Settlements and the Erosion of the Public Realm, 83 GEO. L.J. 2619, 2625 (1995). 
we moving toward a society in which businesses with money make use of private $A D R^{158}$ while others are "consigned to public courts which government will have little incentive to adequately fund because their constituents lack political clout"? ${ }^{159}$ Will the courts suffer the same fate as the public school system? ${ }^{160}$ Perhaps. Thus, the following admonition by Justice Moses Harrison of the Illinois Supreme Court should be kept in mind:

Generally speaking, I'm opposed to dispute resolution and mediation. I know that we need some means to dispose of cases, but I don't believe that sitting around trying to talk things over is an adequate substitute for formal proceedings governed by rules of evidence and presided over by an experienced judge. Our current system is the culmination of centuries of experience, experience which has shown that without rules of evidence, real justice is difficult to achieve. [ADR] may make ... statistics look good, but good statistics don't necessarily reflect an improvement. After all, Mussolini made the trains run on time in Italy, but so what? He had to turn his country into a fascist state to do it. Mediation and alternative dispute resolution proposals are seductive because they promise to reduce costs, but they are dangerous because they are also a means for reducing the power of the courts. These proposals are in direct competition with

Whenever disputants rely on the final and public judgment of a court to resolve their controversy, they enhance the court's claim as an authoritative resolver of controversies. However, when disputants turn elsewhere for resolution - private arbitration, nonjudicial government agencies, or private bargaining-the salience of adjudication fades and the authority of courts weakens.

Id. See also Lauren K. Robel, Private Justice and the Federal Bench, 68 IND. L.J. 891,894 (1993) (contending that the increased use of private justice by litigants undermines the authority of the federal courts).

${ }^{158}$ See, e.g., Reuben, supra note 52, at 55 (noting that fees charged by JAMS rent-a-judges range from $\$ 350$ to $\$ 500$ per hour). Presumably, only wealthy businesses and litigants can afford such rates, thereby creating a two-tier system of justice- one for the "haves" and another for the "have-nots."

${ }^{159}$ Robert L. Haig \& Steven P. Caley, How Clients Can Use Federal Court ADR Methods to Achieve Better Results, 5 FED. LITIG. GUIDE REP. 193, 194 (1994).

${ }^{160}$ See James Podgers, Chasing the Ideal: As More Americans Find Themselves Priced Out of the System, the Struggle Goes on to Fulfill the Promise of Equal Justice for All, A.B.A. J., Aug. 1994, at 56, 61 (analogizing the harm to public education due to loss of public support to the potential harm to the public court system if the big players exit the system for private ADR). 
our court system. Indeed, they threaten to destroy the very system that is the very basis of our profession. They undermine the judiciary by diverting scarce resources away from the courts and by placing the process under the control of people who do not know and have no reason to know any law or rules of evidence. The result, I believe, will be a cutrate brand of rough justice that is neither fair nor consistent, but merely cheap. ${ }^{161}$

\section{PROPOSALS FOR REFORM}

The continued vitality and utility of a contemporary body of commercial common law which is based upon courts' experiences with similar business cases, and the continuing evolution of rules to govern business conduct, requires two things: (1) that there be a substantial pool of business cases processed and decided by our public court system; and (2) that the decisions in those cases be available as precedent and become part of the evolving framework for governing and deciding business and commercial disputes. To ensure that these two things can occur, we propose that the following course corrections be made.

\section{A. Course Corrections to Help Maintain a Sufficient Quantity and Variety of Business Cases at the Trial Court Level}

If the common law is to continue to provide contemporary standards for allocating riskand deciding business and commercial disputes, the court system must be able to attract and process a large number and variety of business cases. Only with a sufficient number and variety of cases can the system operate to fine-tune itself by recognizing patterns of commercial practice and developing common law responses to recurring problems. ${ }^{162}$

${ }^{161}$ Justice Moses Harrison, Keynote Address at the 1996 Illinois Supreme Court dinner (1996), quoted in Lucille M. PONTE \& Thomas D. CavenaGH, ALTERNATIVEDISPUTE RESOLUTIONINBUSINESS 329-30 (1999). Charles Carpenter also notes that with respect to the issue of selective publication and no-citation rules, they "add to [a hostile perception of the courts] by increasing the aura of secrecy over the functioning of the judicial branch and by strengthening the perception that the judiciary is not accountable." Carpenter, supra note 98, at 254.

${ }^{162}$ We know, for example, that only a fraction of cases are resolved by trial. See, e.g., supra notes 114-15 and accompanying text. Thus, if we assume that $95 \%$ of all business cases are settled or otherwise disposed of before trial, and if, of the remaining five percent, half (or more) are denied precedential value due to selective publication, vacatur, or depublication, then by the end of the process few 
The past two decades have seen a number of initiatives, at both the federal and state levels, to improve and reform the court system's processing of cases. Conscious of the fact that "[i] ustice delayed is justice denied,"163 many of these reform initiatives, and the majority of those actually implemented, single out and attempt to address the issue of delay. These initiatives have included the so-called "rocket docket" and "fast track" programs, ${ }^{164}$ judicial management of cases, ${ }^{165}$ structural consolidation initiatives, ${ }^{166}$ closer monitoring and evaluation of the time it takes courts and judges to dispose of cases on their docket, ${ }^{167}$ court-annexed arbitration, ${ }^{168}$ summary jury trials, ${ }^{169}$ and the restriction of diversity

cases remain with which to grow and develop our contemporary body of commercial common law in a meaningful way.

${ }^{163}$ John K. Van de Kamp \& Richard Jacobs, Reducing Time to Trial: The Trial Court Delay Reduction Act of 1986, 1 CAL. LITIG. 9,9 (1987); see also Johnson, supra note 34, at 230 ("The notion that justice delayed is justice denied has repeatedly been recognized and confirmed.").

${ }^{164}$ See Johnson, supra note 34, at 235-37 (discussing the proliferation of rocket docket programs); Friedrichs, supra note 34 , at $445-54$ (discussing one of California's many fast track programs in San Diego County).

${ }^{165}$ See supra note 80 and accompanying text.

${ }^{166}$ See Joan B. Carey, Court Reform: Consolidation of the State's Courts: Judge Kaye's Proposal, 4 CrTY LAw 25 (Mar./Apr. 1998) (describing the court consolidation movement in New York's state courts); David Kline, George Hails Overwhelming Passage of Court Consolidation Measure, METROPOLITAN NEWS-ENTERPRISE, June 4, 1998, at 3 (describing the court consolidation movement in California's state courts); see, e.g., Renee Deger, In Brief, RECORDER, Aug. 3, 1998 (same).

${ }^{167}$ See supra note 84. See also STATEOF CALIFORNIA COMMISSION ON JUDICIAL PERFORMANCE ANNUAL REPORT 17 (1998) (noting that in 1998 eleven judges received an advisory letter or discipline for decisional delay, tardiness, or other dereliction of duty); A. John Pelander, Judicial Performance Review in Arizona: Goals, Practical Effects and Concerns, 30 ARIZ. ST. L. J. 643, 645, 651 (1998) (noting that over the past two decades the concept of evaluating judicial performance-which inciudes managerial skills and punctuality - has been adopted in a number of jurisdictions and that there is a growing trend in that direction); Jona Goldschmidt, Merit Selection: Current Status, Procedures, and Issues, 49 U. MIAMIL. REv. 1, 18 (1994) (noting the recommendation that judicial performance commissions develop judicial evaluations based on criteria such as docket management and prompt case disposition).

${ }^{168}$ See Irving R. Kaufman, Reform for a System in Crisis: Alternative Dispute Resolution in the Federal Courts, 59 FORDHAML.REV. 1, 17-22 (1990) (describing court-annexed arbitration).

${ }^{169}$ See id. at 13-17 (describing the summary jury trial); Ponte, supra note 45, at 1069-84. 
jurisdiction. ${ }^{170} \mathrm{~A}$ number of other reforms have appeared, ranging from specialized business courts, ${ }^{171}$ greater uniformity of laws governing choice of law and choice of forum to increase standardization and comity, ${ }^{172}$ reduced discovery, ${ }^{173}$ and limitations on trial by jury. ${ }^{174} \mathrm{However}$, the extent to which such reforms address and improve the viability and attractiveness of the court system as a forum of choice for business cases remains unclear.

It is widely perceived that many judges lack the background, familiarity, and training in business and commercial practice. ${ }^{175}$ This in part is due to the increased specialization of the law itself ${ }^{176}$ the politicization of judicial selection,,${ }^{177}$ and even to judicial salaries ${ }^{178}$ Today, many trial court judges, at both the state and federal levels, are promoted from positions in

${ }^{170}$ Effective in 1997, Congress increased the jurisdictional amount for diversity cases from $\$ 50,000$ to $\$ 75,000$. See John Flynn Rooney, U.S. Jurisdiction Limit Increases to \$75,000, CHI. DAILY LAW BULL., Jan. 16, 1997, at 1. See also 28 U.S.C. $\$ 1332$ (1999).

${ }^{171}$ See Rochelle C. Dreyfuss, Forums of the Future: The Role of Specialized Courts in Resolving Business Disputes, 61 BROOK. L.REV. 1 (1995) (discussing the trend toward adjudicating business disputes in specialized tribunals). But for a countervailing view of the merits of specialized business courts, see Jeffrey W. Stempel, Two Cheers for Specialization, 61 BROOK. L. REV. 67 (1995).

${ }^{172}$ See generally KENNETH W. CLARKSON ET AL., WEST'S BUSINESS LAW 47778 (1992) (discussion illustrating the wide latitude that courts now give to forum selection and choice of law clauses); SCHAFFER ET AL., supra note 25, at 111 (same). Further, state adoption of section 1-105 of the Uniform Commercial Code, which provides that parties may chose the law that will govern the contract so long as their choice bears a "reasonable relation" to the selected state, was obviously an important step toward increasing uniformity and comity in the choice of law area. See U.C.C. § 1-105 (1995).

${ }^{173}$ See Eric K. Yamamoto, ADR: Where Have the Critics Gone?, 36 SANTA CLARA L. REV. 1055, 1057 (1996) (noting reduced discovery as a reform measure designed to reduce court caseloads and address criticism about waste and delay).

${ }^{174}$ See, e.g., Robert W. Phillips, Note, Cass County Music Co.v. C.H.L.R., Inc.: Law, Equity, and the Right to Jury Trial in Copyright Infringement Suits Seeking Statutory Damages, 51 ARK. L. REV. 117, 121 (1998) (noting that the Eighth Circuit Court of Appeals has held there is a right to a jury trial on both the issues of infringement and the determination of the amount of a "basic"statutory damages award, while other circuit courts of appeals have adopted a conflicting view).

${ }^{175}$ See supra notes 59-63 and accompanying text.

${ }^{176}$ See, e.g., KRONMAN, supra note 100, at 275 (noting how the law has become "more specialized").

${ }^{177}$ See supra note 61.

${ }^{178}$ See supra note 62. 
prosecutorial offices of district attorneys and U.S. attorneys. ${ }^{179}$ Many of these judges come to the bench without any significant experience in business or commercial practice, other than a first year contracts course, and perhaps a commercial or secured transactions course. This lack of familiarity with ordinary and standard commercial and business practices is communicated to the business parties in the courtroom, contributing to a loss of confidence in the court's ability to understand the commercial subject matter itself. ${ }^{180}$

Even when judges are not selected from a criminal prosecution or defense background, they have often had little, if any, actual trial experience. As discussed previously with respect to the so-called "discovery lawyer" problem, ${ }^{181}$ attorneys (and judges) who have not actually tried cases and introduced evidence tend to be "discovery lawyers," and they remain less than comfortable with the actual conduct of trials and the resolution of evidentiary issues. Further, existing continuing education programs for judges have not, for the most part, focused on increasing familiarity with commercial and business practices, although some of the educational programs are aimed at improving trial and evidence skills. ${ }^{182}$

${ }^{179}$ For example, with respect to U.S. district court judges, $40.7 \%$ of President Clinton's appointees came from a prosecutorial background. For Presidents Bush, Reagan and Carter, the figures are $39.2 \%, 44.1 \%$, and $38.1 \%$, respectively. See Goldman \& Slotnick, supra note 61, at 275 tbl. 3.

180 When we say, "communicated in the courtroom," the following is an example that the authors have experienced in many of California's state and federal courts: Due to the complexity of most business cases, a two, three or even fourweek trial is not uncommon. When the court learns that the case will take that long to try, statements to the effect of, "Three weeks! We don't have that kind of time, staff or resources in this building to devote to your case" are not unheard-of. When counsel resists efforts to be diverted into arbitration or mediation and insists on a trial, he or she will often quickly find their case has become a member of a disfavored class. In other words, you pay for your insistence through delay; the court will put your case at the back of the line. Moreover, when the trial finally takes place, the judge's or court personnel's frustration with having to try the case is usually somehow communicated to the jury.

${ }^{181}$ See supra notes 117-18 and accompanying text.

${ }^{182}$ A review of the National Center for State Courts' Course Calendarweb page, Year 2000 Course Calendar (visited Jan. 3, 2000) <http://www.ncsc.dni.us/icm/ 2000 cat/icm2000.htm>, and the Federal Judicial Center's Education L.C.W. web page, Education Materials for Court Personnel (visited Jan. 3, 2000) $<$ http://www.fjc.gov/public/fjcweb.nsf/Pages/54>, reveals a wide variety of continuing education courses for judges to hone their skills, only a handful of which appear to touch on business and commercial cases and issues. 
A closely related issue is that many trial judges, particularly at the state court level, simply are not provided adequate time and staff to address and research issues of law that arise in business and commercial cases. ${ }^{183}$ Finally, there is a perception among many of those representing businesses before state and federal courts that many of the best "business" judges leave the judiciary to either return to private practice, or to enter into the private judging market. ${ }^{184}$ This "robe drain" results in a further loss of familiarity and expertise in business subjects on our benches.

\section{Recommendation One- Expand the Pool of Judicial Candidates}

Barassociations, especially business law sections, and business groups should encourage appointing authorities, or where judges are elected, voters, to expand the candidate pool and appoint or elect judges who have actually practiced in the business transaction or litigation fields prior to assuming the bench. Former prosecutors do not necessarily make good business and commercial dispute resolution judges.

\section{Recommendation Two- Improve Judicial Continuing Education in Business and Commercial Practices}

Judges should be better exposed, through a regular curriculum of continuing education courses, to evolving business and commercial practices. For those judges who have not had extensive trial experience, this curriculum should also include training in trial practice and evidence.

\section{Recommendation Three- \\ Increase the Use of Law Clerks and Research Attorneys to Support Judges}

State trial courts in particular should increase their use of law clerks and research attorneys to provide support to the judges (but not to assume their decision making responsibilities). ${ }^{185}$ This not only better prepares a

${ }^{183}$ See Rubin, supra note 30, at 653.

${ }^{184}$ See Smith, supra note 62.

${ }^{185}$ See supra note 88 and accompanying text (noting how when judges farm out their decision making duties courts risk becoming perceived as impersonal institutions). 
judge to hear business cases, but is also likely to result in improved framing and deciding of issues. This, in turn, should better delineate issues on appeal.

\section{Recommendation Four- Increase Scrutiny of Fee Applications}

Many business disputes involve a written contract. Such contracts between the parties usually provides that in the event of a dispute between them, the prevailing party is entitled to recover its "reasonable attorneys' fees" against the losing party. ${ }^{186}$ At least one commentator argues that such fee shifting has a lottery effect and is akin to an award of punitive damages against the losing party. ${ }^{187}$ Regardless of the merits of that debate, the

${ }^{186}$ Excellent articles exist with respect to the issue of fee shifting, particularly those that have modeled fee shifting regimes in an effort to gauge their impact on litigation and settlement. For a representative sampling, see Symposium, Attorney Fee Shifting, 47 LAW \& CONTEMP. ProBs. 1 (Winter 1984). See also Keith N. Hylton, Fee Shifting and Predictability of Law, 71 CHI.-KENT L.REV. 427, 445-47 (1995) (noting that under a two-way fee shifting scheme, there is an incentive to litigate rather than settle a dispute); Robert S. Miller, Attorneys' Fees for Contractual Non-Signatories Under Civil Code Section 1717: A Remedy in Search of a Rationale, 32 SAN DIEGO L. REV. 535, 541 (1995) ("[F]ee-shifting might discourage settlement. Adding the possibility of recovering fees into the litigants' calculus of the settlement value of their cases could make settlement less likely."). But cf. John J. Donohue III, Opting for the British Rule, or If Posner and Shavell Can't Remember the Coase Theorem, Who Will?, 104 HARV.L.REV. 1093 (1991); and Bradley L. Smith, Note, Three Attorney Fee-Shifting Rules and Contingency Fees: Their Impact on Settlement Incentives, 90 MICH. L. REV. 2154 (1992).

${ }^{187}$ See Bruce L. Hay, Fee Awards and Optimal Deterrence, 71 CH..-KENT L. REV. 505, 514-15 (1995). Hay further notes that when the prospect of fee shifting (or punitive damages) exists, attorneys will invest more in the litigation. See id. at 511-13. For possible examples of this concept in action, see Barbara Steuart, No Joke: $\$ 100$ Dispute Spawns More Than $\$ 1$ Million in Fees, RECORDER, Oct. 21, 1994 , at 1 (discussing a landlord-tenant dispute over a $\$ 100$ fee that yielded an attorneys' fees award of \$422,258); Deane Gardenhome Ass'n v. Denktas, $16 \mathrm{Cal}$. Rptr. 2d 816, 817, 819 (Ct. App. 4th 1993) (where the monetary value of the dispute was less than $\$ 1800$ but the court awarded $\$ 15,000$ in attorneys' fees to the prevailing party). Unfortunately, there is little empirical evidence that illustrates the depth or severity of fee shifting and its impact on settlement and litigation. It has been the authors' experience in California, however, that many trial judges too easily rubber stamp the prevailing party's fee application and are reluctant to disallow any meaningful portion of the requested fees, especially where the client 
important point for purposes of this Article is that many business clients are concerned about this issue; it is one reason why they perceive the public court system to be too expensive and unpredictable, and is yet another reason why some of them are turning to private ADR to revolve their disputes. Thus, in order to maintain the integrity of the public court system and make it a more attractive forum for businesses seeking to resolve their disputes, judges at all levels need to be more diligent about scrutinizing fee applications and ensure that every attorneys' fee award bears a reasonable relation to the hours, rates, and results of the litigation. ${ }^{188}$ If the fees sought are in any way unreasonable, they should be disallowed. ${ }^{189}$

has paid them.

${ }^{188}$ The factors that courts should utilize in determining the amount of a prevailing party's fees sought pursuant to an attorneys' fees provision in a contract are well summarized in Rule 1.5(a) of the Rules of Professional Conduct of the American Bar Association. This rule provides that the factors to be considered in determining the reasonableness of a fee request include the following:

(1) the time and labor required, the novelty and difficulty of the questions involved, and the skill requisite to perform the legal service properly;

(2) the likelihood, if apparent to the client, that the acceptance of the particular employment will preclude other employment by the lawyer;

(3) the fee customarily charged in the locality for similar legal services;

(4) the amount involved and the results obtained;

(5) the time limitations imposed by the client or by the circumstances;

(6) the nature and length of the professional relationship with the client;

(7) the experience, reputation, and ability of the lawyer or lawyers performing the services; and

(8) whether the fee is fixed or contingent.

MODEL RULES OF PROFESSIONAL CONDUCT Rule 1.5(a) (1995). States have a similar provision in their rules of professional conduct. See, e.g., RULES OF PROFESSIONALCONDUCT OF THE STATEBAR OF CALIFORNIA Rule 4-200 (amended 1992).

${ }^{189}$ See, e.g., McGinnis v. Kentucky Fried Chicken, 51 F.3d 805, 810 (9th Cir. 1995) ("Lawyers might reasonably spend $\$ 148,000$ worth of time to win $\$ 234,000$. But no reasonable person would pay lawyers $\$ 148,000$ to win $\$ 34,000$."). Further, California's Sixth District Court of Appeal recently decided that all of the fees incurred after the plaintiff rejected a reasonable but informal settlement proposal were not "reasonably spent" on the litigation and were not compensable by the losing parties. The client had paid more than $\$ 450,000$ of the billed attorneys fees; $\$ 520,587$ was requested, but only $\$ 75,000$ was awarded. Meister v. Regents of University of California, 78 Cal. Rptr. 2d 913, 916-18 (Ct. App. 6th 1998). The authors submit that more trial courts should follow this example. 


\section{Recommendation Five- \\ Businesses Must Become Informed Consumers of Legal Services}

Businesses must become more informed and more sophisticated consumers of legal services. The issue of the corporate law firm and its "discovery lawyers,"190 coupled with litigation expense that is out of proportion to amounts in controversy, require businesses to take more responsibility. ${ }^{191}$ Stated differently, the decision to use a corporate megafirm to handle a company's legal work is not always the best decision. ${ }^{192}$

${ }^{190}$ See supra notes 117-18 and accompanying text.

${ }^{191}$ As an example, one of the authors has taught M.B.A. students for a number of years. The percentage of these students who appear to have little interest in becoming sophisticated users of legal services is striking. The prevailing attitude seems to be, "That is something for my in-house counsel to worry about." While this attitude may be unique to the author's academic institution, we suspect that is not the case. In short, the corporate managers of today and the future need to take more responsibility for alleviating some of the criticisms of traditional litigation. Corporate management should stop pressuring legal counsel to implement overlyaggressive litigation tactics, they should stop unreasonably refusing to settle a case or pay a judgment when their legal counsel advises them to do so, etc. In short, not all of the blame lies with lawyers, judges and the court system.

In their thought-provoking book, No Contest, Ralph Nader and Wesley Smith echo these concerns. See NADER \& SMITH, supra note 57, at 238 ("Clients have to watch out for both overbilling and overlawyering.... The only thing that will slow down billing abuses is aggressive case management by clients." (quoting John Toothman, founder of the Devil's Advocate, and James P. Schratz, previously vice president for major claims at Fireman's Fund Insurance Company)). Id. at 238-39 (listing several practices that management should look for to determine whether overbilling or overlawyering is occurring). See also id. at 252-54 (discussing alternative billing arrangements to traditional hourly billing arrangement, such as flat fee billing and value billing).

${ }^{192}$ In working with in-house counsel, the authors are struck at the manner in which many of them select outside counsel. The selection of outside counsel is often based not on who can do the best job at the best price, but on making certain that in-house counsel is covered in the event things go wrong. In other words, should something go wrong, it will often be much easier for in-house counsel to defend his or her decision to use the corporate megafirm to the board of directors (notwithstanding such a firm's exorbitant legal bills) than a decision to use a smaller, cheaper and perhaps less well-known law firm.

Again, Nader and Smith voice a similar concern:

People working for corporations become risk averse . . . They will do 


\section{B. Course Corrections to Help Increase the Availability and Use of Decisions}

The second thrust of reforms is to ensure that businesses and the public have the benefit of knowing and being able to use the accumulated experience and wisdom of courts in prior cases. This aspect gains importance as the pool of business cases is being reduced or depleted due to private judging or disposition of business cases. The current and growing practices of vacatur, selective publication, no-citation rules, and depublication undermine the availability of this accumulated experience. ${ }^{193}$ Further, the very nature of the self-selection process of a court deciding whether a particular decision or opinion may or should be used for guidance or precedent in other cases is inherently flawed, ${ }^{194}$ and arguably undermines "the flexibility and power of self-development of the Common Law."195

\section{Recommendation Six- Provide More Appellate Judges}

As earlier noted, workload concerns drive the use of selective publication. ${ }^{196}$ Thus, in spite of the political challenges it presents, if judges need more time to engage in traditional judging activities (versus managerial judging), then additional appellate judges (not parajudicial staff) should

anything to avoid making a decision that might cause them trouble. For example, I have never seen an [insurance] adjuster called on the carpet for paying a legal bill $\longrightarrow$ no matter how fraudulent. However, dispute a bill and there could be trouble when the well-connected lawyer creates a stink [with upper corporate management] about his integrity being impugned. The typical adjuster will see this and be intimidated into silence.

NADER \& SMITH, supra note 57, at 237-38 (quoting James P. Schratz, previously vice president for major claims at Fireman's' Fund Insurance Company).

${ }^{193}$ See supra notes 92-112 and accompanying text.

${ }^{194}$ One of the authors represented a petitioner before the United States Supreme Court where certiori was granted from a unanimous court of appeals decision against him, and which was also deemed "not for publication." The case before the Supreme Court, which involved the scope of federal jurisdiction under Section 2 of the Constitution, was reversed by a unanimous Supreme Court, leaving the decision by the court of appeals not to publish its decision as a curious substantive and procedural anomaly. Indeed, the author who represented the petitioner in the case, which has since been cited hundreds of times, continues to receive queries about where other lawyers and scholars can find the court of appeals' opinion.

${ }^{195}$ F.B. Ames, The History of Assumpsit, 2 HARV.L. REV. (pt. 2) 53, 69 (1888).

${ }^{196}$ See supra note 98 and accompanying text. 
be hired to handle the critical work that judges perform-deliberating about, deciding, and writing thoughtful appellate decisions. ${ }^{197}$

\section{Recommendation Seven-}

\section{Permit Citation of Any Decision by an Appellate Court of Record}

There must be a change in applicable rules to permit the citation of any decision by an appellate court of record. This would effectively cause the publication, official or otherwise, of all decisions of a court and avoid the court's self-selection of those cases to be published. It would also be consistent with the traditional common law model. ${ }^{198}$ Indeed, in this age of computers and the Internet, there can be no reasonable objection to the burden or expense of making available all decisions of our appellate courts. If anything, the ability to search cases by computer may promote access to and use of precedent. ${ }^{199} \mathrm{~A}$ related question is the "grandfather clause issue"-i.e., the extent to which past unpublished decisions should be a part of this recommendation. The answer will require careful scrutiny and is left for a later day and subsequent article. At the very least, however, we recommend that the rule be prospective (i.e., that it apply to all appellate decisions starting from the date on which this recommendation takes effect forward).

\section{Recommendation Eight- Bar the Practice of Depublication}

The practice of depublication should be barred in its entirety. If a judgment is good enough to stand, so should the lower appellate court's

${ }^{197}$ For a concurring view, see Carpenter, supra note 98, at 257 (proposing increasing the number of appellate court judges and decreasing the size of parajudicial staff).

${ }^{198}$ See id. at 240 ("If unpublished opinions are to be treated in the traditional common law fashion, then they constitute a source of the first rank; that is, binding authority within the jurisdiction of the deciding court. These unpublished opinions should be citable if they are binding authority.").

${ }^{199}$ See id. at 241 (noting that "experiences and advances in technology continue to challenge [the] position ... that appellate courts should reduce the number of published opinions" in order to alleviate their workload concerns). Id. at $253 \mathrm{n} .41$ ("The argument that unpublished opinions are difficult to find has lost some force with the recent proliferation of on-line research services and circuit-specific CDROMS."). 
opinion. If the higher appellate court does not like the lower appellate court's decision, it has the option of overruling the decision.

\section{CONCLUSION}

We end this Article where we began-with a ballad from Karl Llewellyn. Professor Mary Ann Glendon writes that in the spring of 1961, Professor Llewellyn sang the following ballad for the last time to his law students at the University of Chicago:

Some say our Law's in a sorry plight, and folly its fruition.

The answer to that is to set it right, in the Common Law Tradition Rowdy dowdy doodle-ee-o. ${ }^{200}$

The purpose of this Article has not been to point out that the courts and our system for developing commercial precedent are perfect. We know that they are not. Instead, it has sought to illustrate that in many ways, courts and the common law have served business well. As we look to the future of business dispute resolution in the twenty-first century, we would do well to follow Professor Llewellyn's advice. We submit that in removing the evolution of a common body of public decisional authority from the courts, we are depriving businesses - and those governing and advising them - of the very body of information that might help prevent business disputes in the first place. This policy is both shortsighted and erroneous. Through the course corrections proposed in this Article, our courts and the common law can become more important, attractive, and efficient instruments in regulating and evolving our business and commercial lives.

${ }^{200}$ GLENDON, supra note 1 , at 198. 
